\author{
Andrzej CWYNAR ${ }^{1}$ \\ Wiktor CWYNAR ${ }^{2}$ \\ Piotr ORATOWSKI ${ }^{3}$ \\ Marta STACHOWICZ ${ }^{4}$
}

\title{
CORPORATE CAPITAL STRUCTURE DETERMINANTS OVER THE LATEST GLOBAL CRISIS: THE CASE OF POLAND
}

\begin{abstract}
Capital structure decisions in firms and factors determining them still belong to the most challenging research issues that deserve more empirical studies. The recent global crisis has put the subject into a new perspective as it was clearly related to debt issues. Using panel data and multi factor regression procedure we investigated the diversified sample of almost 4000 public and non-public firms operating in Poland over 2006-2011 period to verify the degree to which the most significant traditional firm-specific factors explain their capital structures. Specifically, our study was aimed at examining the potential differences in the investigated relationships in the pre-crisis years as compared to the crisis ones. We confirmed the previous findings of other researchers concerning the impact profitability and size have on leverage. We showed also that the latest global crisis did not influence significantly capital structure selection patterns observed in our sample despite visible changes in the financial performance of the investigated firms. However, our evidence is inconclusive in terms of the verification of two classic capital structure theories: trade-off and pecking order. Some of our empirical findings may be of a practical importance as they can indicate some desired rearrangements in the institutional environment of firms, including financial markets, and suggest the appropriate directions for the potential policy programs.
\end{abstract}

Keywords: capital structure, leverage, financing, crisis, JEL classification: G32

\section{INTRODUCTION}

In modern theory of the firm, long-term financial decisions consist of investing and financing choices. After roughly 60 years of gathering the empirical evidence, the impact of the way investment projects are financed on firm value is undeniable. However, the issue of capital structure modeling still belongs to crucial facets of financial management, both in theory and in practice.

We investigated 3784 firms operating in Poland during the period 2006-2011 to check the explanatory power of selected firm-specific quantitative variables implied by classic theories as key factors influencing capital structure choices. Our work contributes to the

\footnotetext{
${ }^{1}$ Andrzej Cwynar, Faculty of Administration and Economics, University of Economics and Innovation in Lublin, Poland, e-mail: andrzej.cwynar@wsei.lublin.pl (Author for correspondence)

${ }^{2}$ Wiktor Cwynar, Faculty of Administration and Economics, University of Economics and Innovation in Lublin, Poland

${ }^{3}$ Piotr Oratowski, Splentum Sp. z o.o., Poland

${ }^{4}$ Marta Stachowicz, Faculty of Applied Mathematics, AGH University of Science and Technology, Kraków, Poland.
} 
existing body of evidence in this area in three ways. First, capital structure studies conducted in Poland so far were using mainly listed companies or aggregate data. Little is known about leverage determinants in non-public firms. Secondly, the data utilized in our work comes from different database and reflects financial record of another set of businesses in comparison with those used in previous studies (their authors were acquiring data mostly from Amadeus database in case of large samples of listed and non-listed firms, or from publicly available sources offering data for companies quoted on the stock exchange). Hence, our work can shed additional light on the factors determining financing behavior of Central and Eastern European firms in post-transition period. Finally, our work contains a discussion on leverage determinants patterns in Poland including the potential shifts in the patterns resulting from the latest global crisis which was not studied by other authors.

To summarize, the aim of the article is to examine the robustness of the traditional capital structure theories through testing the extent to which firm-specific quantitative variables promoted by them explain capital structures of the investigated firms, especially during the crisis period.

Our research showed that leverage is positively dependent on size and negatively dependent on profitability, which is in line with majority of the results obtained in other empirical studies carried out in Poland so far. We found also negative relationship between leverage and tangibility. Furthermore, we noticed only slight differences in the results of the capital structure determinant regression models estimated for two subperiods associated with the crisis (2006-2008 and 2009-2011) which would suggest limited impact of the crisis on the way traditional firm-specific variables influence leverage.

The remainder of the paper is organized as follows. In the next section we refer to the theoretical literature on the capital structure choice and practical predictions stemming from it. Then we analyze the empirical findings received by other researchers, mostly in Central and Eastern European countries with special attention paid to Poland. Further, we describe the variables and data used in our empirical investigation and demonstrate the model specification. Finally, we present the empirical findings and discussion around them. The last section concludes the article.

\section{LITERATURE REVIEW}

\section{Capital structure theories}

The existing literature on capital structure attempts to offer some overall typologies of the rich array of theoretical concepts aimed at explaining the equity-debt choice in firms ${ }^{5}$. Nevertheless, two broad schools of reasoning have gained dominant position in regard to this field of study ${ }^{6}$ : trade-off theory and pecking order theory. They differ importantly in

\footnotetext{
${ }^{5}$ See for example J. Gajdka, Teorie struktury kapitatu i ich aplikacja $w$ warunkach polskich, Wydawnictwo Uniwersytetu Łódzkiego, Łódź 2002; E. Chojnacka, Struktura kapitału spótek akcyjnych w Polsce w świetle teorii hierarchii źródel finansowania, CeDeWu, Warszawa 2012; M. Barowicz, Determinanty struktury kapitałowej przedsiębiorstwa. Podejście empiryczne, edu_Libri, Kraków 2015.

${ }^{6}$ R. De Haas \& M. Peeters, The Dynamic Adjustment Towards Target Capital Structures of Firms in Transition Economies, "Economics of Transition" 2006, Vol. 14, No. 1; P. Hernádi \& M. Ormos, Capital Structure and Its Choice in Central and Eastern Europe, "Acta Oeconomica" 2012, Vol. 62, No. 2; P. Hernádi \& M. Ormos, What Managers Think of Capital Structure and How They Act: Evidence from Central and Eastern Europe, "Baltic Journal of Economics" 2012, Vol. 12, No. 2; M. Mateev, P. Poutziouris \& K. Ivanov, On the Deter-
} 
many regards which resulted in considering them as competing approaches by some authors.

Trade-off theory, which grew on the basis of Modigliani-Miller theorem, assumes that firms are driven by benefits and costs of equity versus debt when making their capital structure decisions. In their seminal paper Modigliani \& Miller ${ }^{7}$ concluded that in perfectly competitive market firm capital structure is irrelevant in the sense that it doesn't affect the firm value. Yet, real-life imperfections (fiscal, informational, agency, risk-related etc.) result in some advantages and disadvantages of equity and debt, respectively. Trade-off theory utilizes the imperfections to explain the way firms behave when selecting the capital mix.

Pecking order hypothesis emerged as the theoretical response to the empirical findings of Donaldson ${ }^{8}$ who observed a specific order in which investigated firms were satisfying their financing needs. Internal funds were at the top of the hierarchy. They were followed by debt issuances when internal funds were not sufficient or not available. Raising additional equity was evidenced to be the last resort in financing. The theory, developed by Myers \& Majluf ${ }^{9}$, is based on the information asymmetry between firms' stakeholders and predicts that the order documented by Donaldson can be explained by the costs implied by the asymmetry.

These two theoretical approaches differ in at least two key points. Firstly, trade-off theory in its pure form is static (debt-equity choice is analyzed within the framework assuming fixed amount of total capital) while pecking order theory is dynamic (debtequity choice is analyzed within the framework assuming changes in total capital). Secondly, the financing behavior in which firms trade off the benefits of debt against its costs naturally leads to the expectation of the existence of the optimal capital structure (at which the marginal benefit of debt is the same as the marginal cost). In contrast to trade-off theory, pecking order theory doesn't maintain that firms are driven towards the optimal capital structure while choosing between equity and debt. Instead, it assumes that the driving forces are mainly represented by the firms' past profitability and current needs for investment funds.

The latest papers on capital structure decisions argue that these two clearly distinct theoretical lines of thinking need not to be mutually exclusive ${ }^{10}$. They may be complementary parts of more holistic approach in which trade-off motives may be of greater importance in long-run while pecking order implications may be observable rather in short-run. Such reconciling approach may mean that neither trade-off theory need to be static nor pecking order theory need to neglect the optimal capital structure.

minants of SME Capital Structure in Central and Eastern Europe: A Dynamic Panel Analysis, "Research in International Business and Finance" 2013, Vol. 27, No. 1.

${ }^{7}$ F. Modigliani \& M.H. Miller, The Cost of Capital, Corporation Finance, and the Theory of Investment, "American Economic Review" 1958, Vol. 48, No. 3.

${ }^{8}$ G. Donaldson, Corporate Debt Capacity: A Study of Corporate Debt Policy and the Determination of Corporate Debt Capacity, Harvard School of Business Administration, Boston 1961.

${ }^{9}$ S. Myers \& N. Majluf, Corporate Financing and Investment Decisions When Firms Have Information Investors Do Not Have, "Journal of Financial Economics" 1984, Vol. 13, No. 2.

${ }^{10}$ R. De Haas \& M. Peeters, The Dynamic Adjustment... 


\section{Theoretical predictions}

Firm-specific attributes theoretically affecting the debt-equity choice

The capital structure theories suggest some firm-specific attributes critically important for benefits and costs associated with selecting equity or debt. Many articles discuss the theoretical expectations concerning the way such firm-specific characteristics (and their observable proxies) influence capital structure choices made in firms ${ }^{11}$ to mention only some papers on capital structure choices made in Central and Eastern European firms). Many times their interpretations are different. Because of more multidimensional character of trade-off theory in which "asymmetry information costs are one of many factors that influence firms' capital structure decisions, whereas in a 'pecking order world' these costs are basically the only determinant" ${ }^{\prime 2}$, the set of attributes associated with the trade-off theory is more abundant in the literature. In this section we follow the set of attributes discussed by Titman \& Wessels ${ }^{13}$ in their classic paper to make a brief review of the way the firm-specific characteristics may influence the capital structure decisions according to different theoretical frameworks. The following section also provides the theoretical justification for the independent variables chosen for the empirical study presented in the paper.

Asset structure (tangibility vs. intangibility)

In accordance with both trade-off theory and pecking order theory the collateral value of assets (in majority of empirical studies referred to as "tangibility" or "asset structure") belongs to the firm-specific attributes having arguably the greatest importance in corporate funds selection. However, the relationship between firm asset structure and leverage is ambiguous. Generally, in the light of trade-off theory one can expect the positive link between these two characteristics since collateralizable assets reduce the bankruptcy costs because they can be easily liquidated in case of the default. On the other hand under the asymmetric information circumstances, emphasized by pecking order theory, firms with many collaterizable assets may be inclined to issue more debt because such assets exhibit values known not only to the managers but also to the investors and thus reducing the informational costs. Yet, from the point of view of the owner-manager agency setting more collateral assets may lead to less debt in the capital structure ${ }^{14}$. Despite those controversies, it seems that even within pecking order setting positive relation seems to be more reasonable. From the creditors' point of view tangible assets alleviate the risk they face and thus reduce the likelihood of adverse selection and moral hazard.

\footnotetext{
11 A. Białek-Jaworska, N. Nehrebecka, Struktura kapitatowa przedsiębiorstw w świetle wyników badań, "Zeszyty Teoretyczne Rachunkowości” 2015, Vol. 81, No. 137; M. Kędzior, Capital Structure in EU Selected Countries - Micro and Macro Determinants, "Argumenta Oeconomica" 2012, Vol. 1, No. 28; L. Klapper, V. Sarria-Allende \& V. Sulla, Small- and Medium-Size Enterprise Financing in Eastern Europe (World Bank Policy Research Working Paper 2001, No 2933), http://www1.worldbank.org/finance/assets/images/2933.pdf; P. Bauer, Capital Structure of Listed Companies in Visegrad Countries, "Prague Economic Papers" 2004, Vol. 13, No. 2; N. Mokhova \& M. Zinecker, The Determinants of Capital Structure: The Evidence from the European Union, "Acta Universitatis Agriculturae Et Silviculturae Mendelianae Brunensis" 2013, Vol. 282, No. 7; E. Mostarac \& S. Petrovic, Determinants of Capital Structure of Croatian Enterprises Before and During the Financial Crisis, "UTMS Journal of Economics" 2013, Vol. 4, No. 2.

${ }^{12}$ R. De Haas \& M. Peeters, The Dynamic Adjustment..., p. 145.

${ }^{13}$ S. Titman \& R. Wessels, The Determinants of Capital Structure Choice, "The Journal of Finance" 1988, Vol. 43, No. 1, pp. 1-19.

${ }^{14}$ Ibidem, p. 3.
} 


\section{Non-debt tax shield}

Non-debt tax shield is considered an important attribute influencing the choice of debt ratio in trade-off theory as it serves as the substitute for debt tax shield. Firms that record the same kind of tax savings as those given by debt but coming from other sources (e.g. depreciation and investment tax credits) are less inclined to borrow funds. Thus, trade-off theory predicts negative relation between non-debt tax shields and the share of debt in capital structure. It is reasonable to assume that one should expect negative link between non-debt tax shield and leverage also on the pecking order ground. Depreciation is considered a part of self-financing and hence the greater it is in relation to total assets, the smaller external financing needs, including borrowings.

\section{Growth}

Opinions on the direction in which growth affects capital structure expressed in the theoretical debates are mixed. The attribute doesn't have an apparent status even in tradeoff theory. Majority of authors consider growth to be inversely related to debt ratios of firms. They argue that it can pose a threat of instability resulting in higher uncertainty and thus risk - a significant factor in the trade-off framework. Those expectations are reinforced by the rationale which is behind the agency concerns. Additionally, firms with significant growth potential can have incentives to refrain from borrowing to preserve a financial reserve (the need for such reserve is positive function of growth opportunities Bancel \& Mittoo ${ }^{15}$ ). However, from the point of view of pecking order setting more rapid growth leads to bigger financing needs, including external funds. This means that rapidly growing firms can be forced to borrow more and - as the result - exhibit positive relationship between growth and debt ratios ${ }^{16}$. On the other hand, high growth rates intensify problems and increase costs resulting from asymmetric information since outsiders may not be able to value growth options plausibly ${ }^{17}$. This suggests that growth may have negative impact on leverage even in pecking order regime because firms may be motivated to avoid those costs or at least to reduce them. Some authors argue that the sign of the relationship depends on which debt component (short-term versus long-term) is considered and how it is valued.

\section{Size}

It seems that trade-off and pecking order theories lead to different expectations concerning the sign of the relation between leverage and firm size. Larger firms are less vulnerable to negative factors highlighted in trade-off framework such as forces leading to financial distress and bankruptcy. This can be explained, at least partly, by the diversification of larger firms. Additionally, Titman \& Wessels ${ }^{18}$ point out that in smaller firms direct bankruptcy costs constitute bigger fraction of their value. Also, size determines the access to funds - larger firms face smaller barriers when they strive for external financing, including funds from commercial banks. All of those reasons justify the expectation of

\footnotetext{
${ }^{15}$ F. Bancel \& U.R. Mittoo, The Determinants of Capital Structure Choice: A Survey of European Firms 2002, http://papers.ssrn.com/sol3/papers.cfm?abstract_id=299172.

${ }^{16}$ N. Mokhova \& M. Zinecker, The Determinants of Capital Structure..., p. 2533; R. De Haas \& M. Peeters, The Dynamic Adjustment..., p. 145.

${ }^{17}$ M. Mateev, P. Poutziouris \& K. Ivanov, On the Determinants..., p. 6-7.

${ }^{18} \mathrm{~S}$. Titman \& R. Wessels, The Determinants of Capital..
} 
positive relationship between size and share of debt in capital structure. On the other hand some authors reasonably argue that since larger firms are more transparent and their communication with investors is more intensive, they should experience lower costs of asymmetric information which is essential in pecking order theory ${ }^{19}$. This kind of association was noticed since the influential work of Rajan \& Zingales ${ }^{20}$. Moreover, Mokhova \& Zinecker ${ }^{21}$ claim that larger firms have "more opportunities to achieve greater sales and consequently retain earnings". All of those theoretical findings lead to the expectation of inverse link between leverage and size. Some authors reasonably argue that specificity of some economies make positive relation between size and leverage more probable than negative one. For example De Haas \& Peeters ${ }^{22}$ notice that because of the underdeveloped status of stock market and corporate bond market in transition economies larger firms may have easier access to bank credit, which reinforces the prediction of positive correlation between size and leverage.

\section{Volatility}

In financial management the volatility of operating performance, reflected is such variables as cash flow from operations or any measure of operating income (e.g. EBITDA or EBIT), is considered to be the key determinant of the firm ability to cover the obligations imposed by debt. Hence, the connection of volatility with critical variables of trade-off theory - such as default risk and bankruptcy costs - is straightforward. From the perspective of this particular theory leverage should be decreasing function of volatility. Mateev, Poutziouris \& Ivanov $^{23}$ notice that in the case of operating performance volatility the expectations concerning its relation to leverage are consensual in both theories - trade-off and pecking order. They state that "For the pecking order theory, firms with more volatile cash flows are less likely to have debt in order to lower the possibility that they will have to issue new risky securities or forego future profitable investments when cash flows are low" 24 . In contrast to those predictions De Haas \& Peters ${ }^{25}$ say that positive association of volatility with debt ratio is also likely and justify this assertion by referring to the classic work of Myers (1997) and maintaining that higher volatility can lead to the reduction of the underinvestment problem and - ultimately - agency costs of debt.

\section{Profitability}

According to trade-off theory the extent to which firms use leverage is the resultant of the benefits of debt as compared to its costs. In this particular setting the benefit given by the interest tax shield is of prime importance. However, only firms profitable on the operating level can benefit from it. Additionally, more profitable firms may need more debt to strengthen managerial discipline and relieve agency problems resulting from abundant cash flows. Hence, one can conclude that there should be positive relationship between

\footnotetext{
${ }^{19}$ E. Mostarac \& S. Petrovic, Determinants of Capital Structure of Croatian..., pp. 156.

${ }^{20}$ R.G. Rajan \& L. Zingales, What Do We Know about Capital Structure? Some Evidence from International Data, "The Journal of Finance" 1995, Vol. 50, No. 5, pp. 1421-1460.

${ }^{21}$ N. Mokhova \& M. Zinecker, The Determinants of Capital Structure..., p. 2535.

${ }^{22}$ R. De Haas \& M. Peeters, The Dynamic Adjustment...

${ }^{23}$ M. Mateev, P. Poutziouris \& K. Ivanov, On the Determinants...

${ }^{24}$ Ibidem, p. 9

${ }^{25}$ R. De Haas \& M. Peeters, The Dynamic Adjustment...
} 
profitability and leverage under trade-off theoretical regime. The properties of pecking order theory lead to opposite predictions. In the light of the theory past profitability determines the amount of earnings that can be retained. In the 'pecking order world', the availability of such internally generated funds decreases the willingness of firms to borrow. De Haas \& Peters ${ }^{26}$ add that in the context of severe information asymmetries between firms and banks and higher interest rates resulting from them (in such environment it is harder for banks to distinguish between good and poor firms) one should expect that more profitable firm with the access to the internal financing will prefer it over debt while less profitable businesses without such opportunity will be forced to use debt or external equity in case of financing needs. This allows to assert that leverage can also be negative function of profitability, at least assuming that pecking order is valid.

\section{Financial slack}

Some authors use additional firm-specific attributes to test their explanatory potential in explaining financing behavior predicted by pecking order theory ${ }^{27}$. In our work we follow the selection of Hernádi \& Ormos $^{28}$ who included the availability of internal funds (financial slack) in their regressions. To check the validity of pecking order theory we hypothesized that leverage is a negative function of the financial slack.

\section{Empirical findings of other authors}

In 1988 Titman \& Wessels ${ }^{29}$ pointed out that "Empirical work in this area has lagged behind the theoretical research". Yet, current stock of the empirical findings concerning factors determining capital structures is vast. It seems that the gap was substantially reduced since then. The key reference work in discussion on the empirical evidence as to the capital structure determinants is the extensive survey made by Harris \& Raviv ${ }^{30}$ in which they observed that ,leverage increases with fixed assets, non-debt tax shields, investment opportunities, and firm size and decreases with volatility, advertising expenditures, research and development expenditures, bankruptcy probability, profitability and uniqueness of the product" ${ }^{31}$. However, many other valuable studies were carried out since the publication of the groundbreaking work of Harris \& Raviv. Additionally, their review doesn't include the results of research conducted in Central and Eastern European states, including Poland.

More recent international surveys, yet incomplete, were published not only in the Western countries, but also in Poland ${ }^{32}$. They include such crucial work as Korajczyk \& Levy ${ }^{33}$, Frank \& Goyal $^{34}$, Bevan \& Danbolt ${ }^{35}$, Demirgüç-Kunt \& Maksimovic ${ }^{36}$, Booth,

\footnotetext{
${ }^{26}$ Ibidem.

${ }^{27}$ See for example E. Chojnacka, Struktura kapitału spótek...

${ }^{28}$ P. Hernádi \& M. Ormos, What Managers Think of Capital Structure and How They Act...

${ }^{29} \mathrm{~S}$. Titman \& R. Wessels, The Determinants of Capital..., p. 1.

${ }^{30}$ M. Harris \& A. Raviv, The Theory of Capital Structure, "The Journal of Finance" 1991, Vol. 46, No. 1.

${ }^{31}$ Ibidem, p. 334

${ }^{32}$ See for example A. Białek-Jaworska, N. Nehrebecka, Struktura kapitałowa...; M. Barowicz, Determinanty struktury...; M. Kędzior, Capital Structure in EU...

${ }^{33}$ R.A. Korajczyk \& A. Levy, Capital Structure Choice: Macroeconomic Conditions and Financial Constraints, "Journal of Financial Economics" 2003, Vol. 68, No. 1.
} 
Aivazian, Demirgüç-Kunt \& Maksimovic ${ }^{37}$, De Jong, Kabir \& Nguyen ${ }^{38}$ to mention only a few. To supplement them by Polish cases we searched through the respective literature and recorded more than thirty studies conducted in Poland (published in Polish or in English).

Both Polish and foreign research is diversified. Quantitative research in which regression procedures of various types were used dominates. Nevertheless, some authors (see for instance Graham \& Harvey ${ }^{39}$ or Bancel \& Mittoo ${ }^{40}$ abroad, and Prędkiewicz \& Prędkiewicz ${ }^{41}$ or Luczka $^{42}$ ) utilized qualitative methods (gathering opinions through questionnaires). Further, some authors focused on firm-specific variables while others scrutinized the way leverage is determined by industry-specific or country-specific factors. Moreover, dependent variables (i.e. leverage measures) were selected differently by different authors. Finally, various sets of data and businesses were utilized by them to meet assumed research goals (individual versus aggregate, listed versus non-listed, SME versus large-sized firms etc.).

Polish research we were able to refer to is represented by approximately 30 scientific articles. Interestingly, large part of it was provided by foreign researchers (especially the early studies). In this paper we refer only to the studies aimed at testing the explanatory power of the firm-specific quantitative factors in the context of capital structure decisions. The papers considering qualitative factors and industry-specific as well as countryspecific factors were left undiscussed. However, even the articles dealing with the influence of the firm characteristics on leverage differed in their objectives. In that respect some of them were close to our own study in which we supposed the examination of the dominant capital structure theories in Polish environment. Mateev, Poutziouris \& Ivanov $^{43}$, Hernádi \& Ormos ${ }^{44}$, Mokhova \& Zinecker ${ }^{45}$ represent this sort of papers. Another important category of the empirical work is represented by the papers in which the authors were comparing financing patterns and capital structure behavior in CEE states

${ }^{34}$ M.Z. Frank, \& V.K. Goyal, Trade-off and Pecking Order Theories of Debt (Working paper) 2005, http://www.tc.umn.edu/ murra280/WorkingPapers/Survey.pdf.

${ }^{35}$ A.A. Bevan \& J. Danbolt, Dynamins in the Determinants of Capital Structure in the UK (Working paper 2000/9), http://papers.ssrn.com/sol3/papers.cfm?abstract_id=233551.

${ }^{36}$ A. Demirgüç-Kunt \& V. Maksimovic, Institutions, Financial Markets, and Firm Debt Maturity, "Journal of Financial Economics" 1999, Vol. 54, No. 3; A. Demirgüç-Kunt \& V. Maksimovic, Stock Market Development and Firm Financing Choices, "World Bank Economic Review" 1996, Vol. 10, No. 2.

${ }^{37}$ L. Booth, V. Aivazian, A. Demirgüç-Kunt \& V. Maksimovic, Capital Structures in Developing Countries, "The Journal of Finance" 2001, Vol. 56, No. 1.

${ }^{38}$ A. De Jong, R. Kabir \& T.T. Nguyen, Capital Structure Around the World: The Roles of Firm-and CountrySpecific Determinants, "Journal of Banking and Finance" 2008, Vol. 32, No. 9.

${ }^{39}$ J.R. Graham \& C.R. Harvey, How Do CFOs Make Capital Budgeting and Capital Structure Decisions? "Journal of Applied Corporate Finance" 2002 , Vol. 15, No. 1.

${ }^{40}$ F. Bancel \& U.R. Mittoo, The Determinants of Capital..

${ }^{41}$ K. Prędkiewicz \& P. Prędkiewicz, Wybrane determinanty struktury kapitału mikro, małych i średnich przedsiębiorstw $w$ Polsce, Zeszyty Naukowe Uniwersytetu Szczecińskiego. Finanse, Rynki Finansowe, Ubezpieczenia 2014, Vol. 802, No. 65

${ }^{42}$ T. Łuczka, Struktura kapitału w mikro- i małych przedsiębiorstwach, „Ekonomika i Organizacja Przedsiębiorstwa" 2006, special issue,

${ }^{43}$ M. Mateev, P. Poutziouris \& K. Ivanov, On the Determinants of SME Capital..

${ }^{44}$ P. Hernádi \& M. Ormos, What Managers Think...; P. Hernádi \& Ormos, Capital Structure...

${ }^{45}$ N. Mokhova \& M. Zinecker, The Determinants of Capital... 
(including Poland) with those observed in the Western countries. Such oriented papers come mainly from nineties of XXth. century and first decade of this century as the researchers were curious about the way economic transition process affects the equitychoice model (see for example Cornelli, Portes \& Schaffer ${ }^{46}$; Weill ${ }^{47}$; Hall, Hutchinson \& Michaelas ${ }^{48}$ ). Finally, a number of researchers calibrated the objectives of their studies in significantly distinct way, yet still examining the link between selected firm-specific factors and debt ratios (see for instance Mateus \& Terra $^{49}$ or Shamshur ${ }^{50}$ ).

Making conclusions on the basis of the empirical studies carried out in Poland must take into account the fact that only some of them were examining businesses operating in Poland separately. Large part of the empirical work (especially provided by foreign authors) is based on joined data composed of Polish and other CEE countries' cases. This may impede cross-country comparisons. Additionally, the researchers we refer to, utilized differentiated proxies of the same firm-specific attributes as well as leverage measures in their analyses. This also may impose some difficulties in the overall summative assessments since the empirical evidence proved the significance of the dependent and explanatory variables choice for the final results many times (see for example Bevan \& Danbolt ${ }^{51}$; Kirch, Mateus \& Terra ${ }^{52}$; different results for ROA and ROS as the explanatory variables in Jędrzejczak-Gas ${ }^{53}$ ). The most noticeable differences apply to the proxies of growth / growth opportunities. Some authors (e.g. Klapper, Sarria-Allende \& Sulla ${ }^{54}$ ) adapted the growth in sales revenues as the estimate of the growth while other chosen assets change $\left(\right.$ Weill $\left.^{55}\right)$, the share of the intangible assets in total assets (Mateus \& Terra ${ }^{56}$ Kirch,

${ }^{46}$ F. Cornelli, R. Portes \& M. Schaffer, Financial Structure of Firms in the CEECs [in:] O. Bouin, F. Coricelli, \& F. Lemoine (Eds.), Different Paths to a Market Economy. China and European Economies in Transition (pp. 171-197), OECD 1998, http://www.keepeek.com/Digital-Asset-Management/oecd/development/different -paths-to-a-market-economy-china-and-european-economies-in-transition_9789264163010-en\#page183.

${ }^{47} \mathrm{~L}$. Weill, Determinants of Leverage and Access to Credit: Evidence on Western and Eastern Europe Countries 2002, http://www.researchgate.net/publication/253293146_ Determinants_of_Leverage_and_Access_to _Credit_Evidence_on_Western_and_Eastern_Europe_countries; L. Weill, What Determines Leverage in Transition Countries? "Czech Journal of Economics and Finance" 2004, Vol. 54, No. 5-6.

${ }^{48}$ G. Hall, P. Hutchinson \& N. Michaelas, East and West: Differences in SME Capital Structure Between Former Soviet-Bloc and Non Soviet-Bloc European Countries 2006, http://www.gregoriae.com/ dmdocuments/m56.pdf.

${ }^{49}$ C. Mateus, P.R.S. Terra, Leverage and Maturity Structure of Debt in Emerging Markets, "Journal of Mathematical Finance" 2013, Vol. 3, No. 3A, http://papers.ssrn.com/sol3/papers.cfm?abstract_id=2353638.

${ }^{50}$ A. Shamshur, Access to Capital and Capital Structure of the Firm (CERGE-EI Working Paper 2010, No. 429), https://www.cerge-ei.cz/pdf/wp/Wp429.pdf.

${ }^{51}$ A.A. Bevan, J. Danbolt, Dynaminis in the...

${ }^{52}$ G. Kirch, C. Mateus \& P.R.S. Terra, Country Governance Structure and Financial Development as Determinants of Firms' Capital Structure, "Journal of Money, Investment and Banking" 2012, No. 26, pp. 6-24, http://papers.ssrn.com/sol3/papers.cfm?abstract_id=2353663\&download=yes.

${ }^{53}$ J. Jędrzejczak-Gas, Struktura kapitalu w matych i średnich przedsiębiorstwach, ,Zeszyty Naukowe Uniwersytetu Szczecińskiego. Finanse, Rynki Finansowe, Ubezpieczenia” 2013, Vol. 766, No. 62,

${ }^{54}$ L. Klapper, V. Sarria-Allende \& V. Sulla, Small- and Medium...

${ }^{55}$ L. Weill, Determinants of Leverage and Access to Credit: Evidence on Western and Eastern Europe Countries 2002, http://www.researchgate.net/publication/253293146_ Determinants_of_Leverage_and_Access_ to_Credit_Evidence_on_Western_and_Eastern_Europe_countriess

${ }^{56}$ C. Mateus, P.R.S. Terra, Leverage and Maturity Structure of Debt in Emerging Markets, "Journal of Mathematical Finance" 2013, Vol. 3, No. 3A, pp. 46-59, http://papers.ssrn.com/sol3/papers.cfm?abstract _id $=2353638$. 
Mateus \& Terra ${ }^{57}$; Mateev, Poutziouris \& Ivanov $^{58}$ ) or market to book ratio (Chojnacka ${ }^{59}$; Szudejko ${ }^{60}$ ). Is some studies only one dependent variable was tested (Weill ${ }^{61}$; De Haas \& Peeters $^{62}$; Shamshur ${ }^{63}$ ) while other applied until four (Dević \& Krstić ${ }^{64}$; Klapper, SarriaAllende \& Sulla ${ }^{65}$; Frąckowiak, Gryglewicz, Stobiecki, Stradomski \& Szyszka ${ }^{66}$ ).

The surveyed studies show that generally, despite an obvious specificity, the financing patterns in Poland are not only similar to those in other CEE countries, but also to the capital structure selection models known from the empirical investigations made in Western countries. This is evident from the latest empirical inquiries which unequivocally confirm the convergence (Hernádi \& $\operatorname{Ormos}^{67}$ ) as compared to the studies based on the data describing the early stage of the economic transformation (Cornelli, Portes \& Schaffer ${ }^{68}$; Hussain \& Nivorozhkin ${ }^{69}$; Hall, Hutchinson \& Michaelas ${ }^{70}$ ).

In general, the survey also indicates that the most significant capital structure explanatory variables are size and profitability (although some exceptions exist; for example size was found to be statistically insignificant in Hernádi \& Ormos ${ }^{71}$ while profitability - in Jõeveer $^{72}$. Size was verified as factor significantly and positively related with leverage in almost all surveyed studies which strongly supports trade-off theory. However, almost all studies in which profitability was statistically significant showed its inverse relation with debt ratios which is in line with pecking order theory.

Moreover, Ciołek \& Koralun-Bereźnicka ${ }^{73}$ as well as Mateev, Poutziouris \& Ivanov $^{74}$ showed that size can differentiate companies as to the way other firm-specific factors

${ }^{57}$ G. Kirch, C. Mateus \& P.R.S. Terra, Country Governance Structure...

${ }^{58}$ Mateev M., Poutziouris P. \& Ivanov K., On the Determinants of SME Capital Structure in Central and Eastern Europe: A Dynamic Panel Analysis, "Research in International Business and Finance" 2013, Vol. 27, No. 1.

${ }^{59}$ E. Chojnacka, Struktura kapitału spótek akcyjnych $w$ Polsce...

${ }^{60}$ M. Szudejko, Analiza zależności pomiędzy branża a struktura kapitału przedsiębiorstwa na podstawie wyników finansowych polskich spólek gietdowych, „Zeszyty Naukowe Uniwersytetu Szczecińskiego. Finanse, Rynki Finansowe, Ubezpieczenia” 2013, Vol. 766, No. 62, pp. 701-711.

${ }^{61}$ L. Weill, What Determines Leverage in Transition Countries? "Czech Journal of Economics and Finance" 2004, Vol. 54, No. 5-6.

${ }^{62}$ R. De Haas \& M. Peeters, The Dynamic Adjustment Towards Target Capital...

${ }^{63}$ A. Shamshur, Access to Capital and Capital...

${ }^{64}$ A. Dević \& B. Krstić, Comparatible Analysis of the Capital Structure Determinants in Polish and Hungarian Enterprises - Empirical Study, Facta Universitatis (Series: Economics and Organization), 2001, Vol. 1, No. 9.

${ }^{65}$ L. Klapper, V. Sarria-Allende \& V. Sulla, Small- and Medium...

${ }^{66}$ W. Frąckowiak, S. Gryglewicz, P. Stobiecki, M. Stradomski \& A. Szyszka, Polityka ksztaltowania struktury kapitału $w$ polskich przedsiębiorstwach na tle wybranych krajów Unii Europejskiej [in:] J. Ostaszewski (Ed.), Finanse przedsiębiorstwa (pp. 153-172), Oficyna Wydawnicza SGH, Warszawa 2005.

${ }^{67}$ P. Hernádi \& M. Ormos, Capital Structure and...; P. Hernádi \& M. Ormos, What Managers Think of Capital Structure and How They Act...

${ }^{68}$ F. Cornelli, R. Portes \& M. Schaffer, Financial Structure of Firms...

${ }^{69}$ Q. Hussain \& E. Nivorozhkin, The Capital Structure of Listed Companies in Poland 1997 (IMF Working Paper No WP/97/1975), http://www.imf.org/external/pubs/ft/wp/wp97175.pdf.

${ }^{70}$ G. Hall, P. Hutchinson, \& N. Michaelas, East and West: Differences in SME...

${ }^{71}$ P. Hernádi \& M. Ormos, What Managers Think of Capital Structure...

${ }^{72}$ K. Jõeveer, Sources of Capital Structure: Evidence from Transition Countries (Bank of Estonia Working Paper No 2/2006), 2006, https://www.eestipank.ee/sites/.../files/.../_wp_206.pdf.

${ }^{73}$ D. Ciołek \& J. Koralun-Bereźnicka, Czy wielkość przedsiębiorstwa różnicuje sitę oddziaływania czynników krajowych i branżowych na strukturę kapitału? „Bank i Kredyt” 2014, Vol. 45, No. 3. 
influence leverage. For example, Ciołek \& Koralun-Bereźnicka ${ }^{75}$ proved that both investigated independent variables - profitability and asset structure - were insignificant as the predictors of capital structure choices in the entire population, yet they turned out to be significant after dividing the population into three size classes. Mateev, Poutziouris \& Ivanov $^{76}$ add that the same phenomenon is valid for firm age.

The surveyed studies indicate that growth belongs to the most significant capital structure determinants with positive impact on leverage, in contrast to the prediction of most theoretical interpretations (both trade-off and pecking order theory suggests that corporate debt ratios are inversely related to the attribute). On the contrary, non-debt tax shield, recognized as one of the most relevant capital structure determinants in the trade-off theory, was generally found to be insignificant in majority of surveyed studies.

The most interesting findings concern volatility and tangibility. Volatility is considered an important factor affecting capital structure choice in both theoretical settings trade-off as well as pecking order, as we commented in previous section. Surprisingly, it was proved to be insignificant in relatively large portion of the entire set of studies conducted so far (see for example Delcoure ${ }^{77}$; Kirch, Mateus \& Terra $^{78}$; De Haas \& Peeters ${ }^{79}$; Hernádi \& Ormos $^{80}$. Kirch, Mateus \& Terra ${ }^{81}$ try to explain the phenomenon by the deficiencies of the selected proxies used to estimate volatility. In the research in which volatility was statistically significant, the researchers noticed rather inverse than direct relationship between the factor and leverage (e.g. Bauer ${ }^{82}$; Hall, Hutchinson \& Michaelas $^{83}$ ) for short-term leverage) which is in accordance with trade-off theory. The findings regarding the asset structure (in the sense of their tangibility) were particularly inconclusive. Those studies which exploited not only total leverage but also short- and long-term debt ratios as the dependent variable explicitly showed that the sign of the relation between tangibility and leverage depends on the selected measure of debt, thus confirming the observations made earlier in more developed countries. They revealed that long-term debt ratio is positive function of tangibility, while short-term debt ratio depends negatively on the factor (see for example Hall, Hutchinson \& Michaelas ${ }^{84}$; Kirch, Mateus \& Terra ${ }^{85}$; Shamshur ${ }^{86}$; Mateev, Poutziouris \& Ivanov ${ }^{87}$; Mokhova \& Zinecker $^{88}$ 2013; Kędzior ${ }^{89}$ ).

\footnotetext{
${ }^{74}$ M. Mateev, P. Poutziouris \& K. Ivanov, On the Determinants of SME Capital...

${ }^{75}$, D. Ciołek \& J. Koralun-Bereźnicka, Czy wielkość przedsiębiorstwa...

${ }^{76}$ M. Mateev, P. Poutziouris \& K. Ivanov, On the Determinants of SME Capital...

${ }^{77}$ N. Delcoure, The Determinants of Capital Structure in Transitional Economies, "International Review of Economics and Finance" 2007, Vol. 16, No. 3.

${ }^{78}$ G. Kirch, C. Mateus \& P.R.S. Terra, Country Governance Structure and Financial Development...

${ }^{79}$ R. De Haas \& M. Peeters, The Dynamic Adjustment Towards Target...

${ }^{80}$ P. Hernádi \& M. Ormos, Capital Structure and...; P. Hernádi \& M. Ormos, What Managers Think of Capital Structure and How They Act..

${ }^{81}$ G. Kirch, C. Mateus \& P.R.S. Terra, Country Governance Structure and Financial Development...

${ }^{82}$ P. Bauer, Capital Structure of Listed Companies..

${ }^{83}$ G. Hall, P. Hutchinson, \& N. Michaelas, East and West: Differences in SME Capital...

${ }^{84}$ Ibidem.

${ }^{85}$ G. Kirch, C. Mateus \& P.R.S., Country Governance Structure and Financial Development...

${ }^{86}$ A. Shamshur, Access to Capital and Capital...

${ }^{87}$ M. Mateev, P. Poutziouris \& K. Ivanov, On the Determinants of SME Capital...

${ }^{88}$ N. Mokhova \& M. Zinecker, The Determinants of Capital Structure...
} 
Rarely financial slack has been the subject of the empirical analyses. Those researchers who included the factor in their tests found leverage to be negative function of it (Hernádi \& Ormos ${ }^{90}$; Mateev, Poutziouris \& Ivanov $^{91}$ ).

\section{DATA, VARIABLES AND RESEARCH METHODS}

Data

We utilized the annual panel data of the firms which were obliged to submit their financial statements to Polish Monitor B database over the period 2006-2011. The data was acquired from Splentum database. The selection of the period resulted from both the objectives of the study (the importance of the crisis interval) and the availability of data. The database includes income statements and balance sheets of both public and non-public firms. We removed the following firms from the sample: (1) those without the continuity of financial statements during 2006-2011 period, (2) financial institutions of all kinds, (3) businesses which exhibited negative equity for at least one year within 2006-2011 period. After those removals the final sample consisted of 3784 firms representing 18 sectors (according to the code list of classification of business activities in Poland in 2007). The distribution of the sample firms among the sectors is presented in the appendix.

\section{Dependent variables}

The survey of the empirical research dedicated to the capital structure choice and conducted so far shows that their authors applied various measures of leverage as the dependent variables. The most commonly used estimates were those discussed by Rajan \& Zingales $^{92}$ in their prominent work, i.e. total liabilities to total assets ratio and total debt to total capital (sum of total debt and equity) ratio. Most authors agree with the assertion of Rajan \& Zingales according to which the share of total debt in total capital seems to be the most appropriate measure of leverage for capital structure exploration purposes (see for example Duliniec ${ }^{93}$, Białek-Jaworska \& Nehrebecka ${ }^{94}$ in Polish literature), though the exclusion of trade credit and similar items from the leverage definition may not be sufficiently justified in some cases.

As later empirical evidence showed, the choice of the leverage ratio can significantly affect the study results. Bevan \& Danbolt ${ }^{95}$, who utilized several individual components of debt as the dependent variables instead of traditional aggregate leverage measures, pioneered this line of examination and proved that the 'broadness' of leverage definition matters in the capital structure decisions. Thus, more recent studies have often used longterm and short-term debt, scaled by more of less broadly defined capital or total assets, as the measures of leverage (e.g. Klapper, Sarria-Allende \& Sulla ${ }^{96}$; Weill ${ }^{97}$; Hall,

\footnotetext{
${ }^{89}$ M. Kędzior, Capital Structure in EU Selected Countries...

${ }^{90}$ P. Hernádi \& M. Ormos, Capital Structure and...; P. Hernádi \& M. Ormos, What Managers Think of Capital Structure and How They Act...

${ }^{91}$ M. Mateev, P. Poutziouris \& K. Ivanov, On the Determinants of SME Capital...

${ }^{92}$ R.G. Rajan \& L. Zingales, What Do We Know about Capital Structure? Some Evidence from International Data, "The Journal of Finance" 1995, Vol. 50, No. 5.

${ }^{93}$ A. Duliniec, Struktura i koszt kapitalu w przedsiębiorstwie, PWN, Warszawa 1998.

${ }^{94}$ A. Białek-Jaworska, N. Nehrebecka, Struktura kapitałowa przedsiębiorstw...

${ }^{95}$ A.A. Bevan \& J. Danbolt, Dynamins in the Determinants of Capital...

${ }^{96}$ L. Klapper, V. Sarria-Allende \& V. Sulla, Small- and Medium...
} 
Hutchinson \& Michaelas ${ }^{98}$; Delcoure ${ }^{99}$; Mateev, Poutziouris \& Ivanov ${ }^{100}$; Mokhova \& Zinecker ${ }^{101}$ in CEE studies). Kędzior ${ }^{102}$ points out that the respective literature reveals two 'schools of thinking' - one which claims that the capital structure studies should be based solely on long-term debt and the other one promoting the 'aggregate approach', i.e. the view that the capital structure consideration must include not only long-term component of debt but also the short-term one. Yet, as we mentioned earlier, the split of the entire debt into short- and long-term parts proved to matter in many empirical analyses.

Another important issue in the discussion on the proper leverage measure is the choice between book and market values of the capital. Despite the belief of some authors that "the ratios using market values provide better specification" used book values in their studies. They defended such choice by pointing out that most CFOs make their decisions on the basis of book values of the capital ${ }^{104}$ or by referring to the high volatility of market values which have severe repercussions in the measurement process. Other weren't able to get them as they decided to explore non-traded firms for which market values are unobservable. Finally, a body of evidence exists which shows that the utilization of book values instead of market values doesn't influence research results substantially ${ }^{105}$.

In our study we adopted the broadest measure of leverage - the ratio of total liabilities to total assets, based on book values. This corresponds to the ratio of non-equity liabilities to total assets utilized by Rajan \& Zingales ${ }^{106}$.

\section{Independent variables}

We followed Titman \& Wessels ${ }^{107}$ in selecting the independent variables to our model. Thus, we adapted six firm-specific attributes studied by them: (1) asset structure (following more recent studies we referred to them as intangibility and tangibility), (2) non-debt tax shield, (3) growth, (4) size, (5) volatility, and (6) profitability. The details concerning the respective proxies of the attributes are given in the appendix. In two cases - asset structure and profitability - we decided to use more than one proxy of the selected attribute. Further, we included additional attribute in our investigation, i.e. cash as the measure of the financial slack (or availability of the internal funds), which could allow us for more

\footnotetext{
${ }^{97}$ L. Weill, Determinants of Leverage and Access to Credit: Evidence on Western and Eastern Europe Countries 2002, http://www.researchgate.net/publication/253293146__ Determinants_of_Leverage_and_Access_to_Credit_Evidence_on_Western_and_Eastern_Europe_countries.

${ }^{98}$ G. Hall, P. Hutchinson \& N. Michaelas, East and West: Differences in SME Capital...

${ }^{99}$ N. Delcoure, The Determinants of Capital Structure in Transitional Economies, "International Review of Economics and Finance" 2007, Vol. 16, No. 3.

${ }^{100}$ M. Mateev, P. Poutziouris \& K. Ivanov, On the Determinants of SME Capital...

${ }^{101}$ N. Mokhova \& M. Zinecker, The Determinants of Capital..

${ }^{102}$ M. Kędzior, Capital Structure in EU Selected Countries.

${ }^{103}$ K. Campbell \& M. Jerzemowska, Capital Structure Decisions Made by Companies in a Transitional Economy: the Case of Poland [in:] D. Zarzecki (Ed.), Financial Management. Objectives - Organization - Tools (pp. 51-76), Fundacja Rozwoju Rachunkowości w Polsce, Warszawa 2001.

${ }^{104}$ See for example M. Hamrol \& J. Sieczko, Czynniki kształtujące strukturę kapitału polskich spótek giełdowych, „Prace i Materiały Wydziału Zarządzania Uniwersytetu Gdańskiego” 2006, No. 1.

${ }^{105}$ See R. De Haas \& M. Peeters, The Dynamic Adjustment..., p. 141.

${ }^{106}$ R.G. Rajan \& L. Zingales, What Do We Know about Capital...

${ }^{107}$ S. Titman \& R. Wessels, The Determinants of Capital...
} 
scrutinized examination of pecking order theory which refers to significantly less number of the firm-specific characteristics in comparison to trade-off theory. In doing so we can confront our results with work of Hernádi \& Ormos ${ }^{108}$ as well as Mateev, Poutziouris \& Ivanov $^{109}$ who also included the feature in the empirical research. Moreover, for the same reason we used additional proxy for profitability (return on equity) in comparison with Titman \& Wessels ${ }^{110}$. The motivation to do that stems from the empirical observations of other authors which show that, in contrast to the predictions of trade-off theory, profitability is inversely related to leverage in most studies. We were curious if the alternation of the profitability proxy will hold the validity of the observation. Moreover, because our sample is mixed (it includes both, manufacturing and service firms), ROE may be a more adequate capital structure predictor as compared to other metrics of profitability ${ }^{111}$. Finally, we excluded Titman \& Wessels's uniqueness from our study because we were not able to gather data necessary to estimate the respective proxy. Furthermore, for the same reason (missing data) we had to reject some proxies of non-debt tax shield and growth utilized by Titman \& Wessles.

\section{Model specification}

The empirical analysis of the factors determining leverage ratio was conducted in two steps. Initially, we utilized single factor analysis based on OLS regression procedure. It was aimed at selecting and rejecting some explanatory variables, if necessary, because of the collinearity, or as the result of low correlation with the dependent variable along with p-value exceeding assumed level. Another step was the utilization of the multiple linear regression in order to estimate the explanatory power of the qualified independent variables. To do that we followed Hellwig ${ }^{112}$ method to select the explanatory variables to the following model:

$Y=\alpha_{0}+\alpha_{1} X_{1}+\alpha_{2} X_{2}+\ldots+\alpha_{n} X_{n}+\varepsilon$,

where:

$\mathrm{Y}$ - dependent variable (leverage measure),

$\alpha_{0}-$ the intercept,

$\alpha_{1} \ldots \mathrm{n}-$ the slope coefficients for independent variables,

$\mathrm{X}_{1 \ldots \mathrm{n}}$ - independent variables (firm-specific financial attributes),

$\varepsilon$ - random error term.

Hellwig method allows for the selection of the independent variables combination having the greatest information content (i.e. independent variables strongly correlated with the dependent variable and at the same time weakly correlated each other).

Such regression procedure was used separately for three periods of time: entire 20062011 period, and two sub-periods - 2006-2008 (labelled as "pre-crisis") and 2009-2011 (labelled as "crisis"). The time frames of the latest global crisis are disputable and other

\footnotetext{
${ }^{108}$ Hernádi P. \& Ormos M., Capital Structure and...; Hernádi P. \& Ormos M., What Managers Think of Capital Structure and How They Act.

${ }^{109}$ M. Mateev, P. Poutziouris \& K. Ivanov, On the Determinants of SME Capital...

${ }^{110}$ S. Titman \& R. Wessels, The Determinants of Capital Structure Choice...

${ }^{111}$ L. Klapper, V. Sarria-Allende \& V. Sulla, Small- and Medium...

${ }^{112}$ Z. Hellwig, On the optimal choice of predictors [in:] Z. Gostkowski (Ed.), Toward a system of quantitative indicators of components of human resources development (pp. 171-197), UNESCO, Paris 1968, http://unesdoc.unesco.org/images/0015/001585/158559eb.pdf.
} 
authors adapt various dates to mark them. Poland belongs to the countries which were affected by the crisis to a lesser degree and somewhat later than other economies which is reflected in the main macroeconomic indicators ${ }^{113}$. Hence, we assumed that the division of the entire research period into two equal sub-periods seems to be credible approximation of the pre-crisis and crisis timespans.

While conducting multiple regression linear models have been fitted for the appropriate datasets (Constant effect model for panel data).

Ordinary Least Squares (OLS) estimator is optimal, when it is BLUE (Best Linear Unbiased Estimator) with minimum variance. In order for OLS to be BLUE with minimum variance, the model must satisfy a set of conditions known as Gauss-Markov theorem assumptions $^{114}$.

To attest if the model fitted using OLS method is valid, the following conditions regarding error term should be verified:

1) no serial correlation (if the errors are autocorrelated, OLS is still unbiased however it is not effective),

2) homoscedasticity (if errors are heteroscedastic, OLS is still unbiased, but it has not got the smallest variance, therefore it is no longer BLUE).

3) normality (non-normality of residuals implies we cannot produce reliable confidence intervals in model forecasting process),

Panel data models exhibit various types of serial correlation: individual and group effects as well as heteroscedasticity.

In case the model data exhibits some form of autocorrelation and/or heteroscedasticity, model parameters can typically still be estimated consistently using the usual estimating functions, but for valid inference in such models a consistent covariance matrix estimate is essential.

Several procedures for heteroscedasticity consistent (HC) and for heteroscedasticity and autocorrelation consistent (HAC) covariance estimation have been suggested in the econometrics literature ${ }^{115}$ Driscoll $\&$ Kraay $^{116}$, among others) and are now routinely used in econometric analyses.

They allow to produce valid significance tests, for the estimates obtained via standard OLS estimation process as well as testing the model stability. In our study HAC covariance estimates have been applied as described in Zeileis ${ }^{117}$ with zero weights and HC0 type.

The details concerning the results of our models utilization are given in the appendix.

\footnotetext{
${ }^{113}$ See for example M. Wypych, Równowaga finansowa przedsiębiorstw przemyslowych $w$ okresie spowolnienia finansowego, Zeszyty Naukowe Politechniki Śląskiej (seria Organizacja i Zarządzanie), 2014, Vol. 73, No. 1919.

${ }^{114}$ J.M. Wooldridge, Introductory Econometrics: A Modern Approach, South-Western College Pub, Mason 2013.

${ }^{115}$ A. Zeileis, Econometric Computing with HC and HAC Covariance Matrix Estimators, "Journal of Statistical Software" 2004, Vol. 11, No. 10

${ }^{116}$ J. Driscoll \& A. Kraay, Consistent Covariance Matrix Estimation With Spatially Dependent Panel Data, "The Review of Economics and Statistics" 1998, Vol. 80, No. 4.

${ }^{117}$ A. Zeileis, Econometric Computing with HC...
} 


\section{RESULTS AND DISCUSSION}

\section{Entire period (2006-2011)}

The descriptive statistics estimated in our study reveal some important and interesting phenomena. Firstly, the variability of the leverage ratio does not seem to be significant in the observation period. The difference between 2006 median maximum and 2009 median minimum is 4 p.p. The ratio was consistently decreasing between 2006 and 2009 and then - after reaching the periodical minimum (in 2009) - increase in the ratio was noticed. Such observations do not allow for unambiguous conclusions concerning the impact crisis had on leverage. Knowing that the influence of the crisis on Polish economy was moderate and delayed, it seems that one should not consider the decline in median leverage ratio in years 2006-2009 a crisis effect. Rather, assuming the presumable time lags, the increase in the ratio between 2009-2011 is more likely result of the crisis. Secondly, the deterioration in the economic situation manifested itself mainly in the fall of both profitability and asset growth rate. All three applied measures show that profitability dropped dramatically in 2008 as compared to 2007 when they reached its periodical maximum, and was still falling in the subsequent years until the end of the observed period. For ROE the decline achieved 50\% (37\% for both ROA and ROS, for comparison). This may mean that 2008 could be considered crisis year. Yet, we assumed after all that the shifts in capital structure decisions resulting from the weaker economy would be somewhat deferred. Our data also shows serious decline in the asset growth ratio, by almost $87 \%$ between 2006 and 2009. As distinct from profitability, which was consistently falling through the end of the observation period, the growth rate was found increasing in two last years of the period. Other variables remained relatively constant during the entire research period (the share of tangible assets $-60-63 \%$, the share of depreciation in total assets $-3,5-4,1 \%$, the share of cash in total assets $-6,5-7,5 \%$ ).

We found that leverage is negatively dependent on tangibility which was of a surprise to us. The inverse relationship between tangibility and leverage is against both trade-off and pecking order theoretical predictions, yet it was empirically validated many times in CEE countries, in Poland as well. However, the track record of the empirical studies conducted in Poland since the beginning of the economic transformation seems to suggest that the relationship is gradually reversing into positive which would manifest the maturation of Polish economy (most of the western studies found positive dependence of leverage on tangibility which is in line with the predictions of both theoretical schools - see Cwynar, Cwynar \& Dankiewicz ${ }^{118}$ for discussion). There are at least three possible explanations of such findings. Firstly, even though Poland formally completed the transition process, it may still have some properties of the transitional economy. Secondly, a fraction of total liabilities does not need the collateral. This is very likely in Poland since the debt structure is dominated by short-term borrowings ${ }^{119}$. This line of reasoning seems to be empirically confirmed by some researchers. For example Mokhova \& Zinecker ${ }^{120}$ found for Poland that even though long-term debt ratio is positively dependent on tangibility,

\footnotetext{
118 A. Cwynar, W. Cwynar \& R. Dankiewicz, Studies of Firm Capital Structure Determinants in Poland: An Integrative Review, e-Finanse 2015, Vol. 11, No. 4.

${ }^{119}$ See A. Białek-Jaworska, A. Dzik \& N. Nehrebecka, Wpływ polityki monetarnej na źródła finansowania przedsiębiorstw w Polsce w latach 1995-2012 (Materiały i Studia nr 304), Narodowy Bank Polski, Warszawa 2014.

${ }^{120}$ N. Mokhova \& M. Zinecker, The Determinants of Capital..
} 
there is negative relationship between tangibility and short-term debt ratio. To test the hypothesis in our sample, we built two additional regression models with short-term debt (STD) and long-term debt (LTD) as dependent variables, respectively. As the result, tangibility turned out to be statistically significant only in LTD model, and negatively associated with the dependent variable (the results can be obtained upon the request). Finally, some authors suggest that "where leverage behavior does not have a strategic long-term target, assets tangibility will exert a negative impact on external financing needs"121. This may be compelling explanation since the empirical studies show limited role of the optimal capital structure concept in Poland ${ }^{122}$.

Our results concerning the sign of the relationship between profitability and leverage are consistent with the findings of other authors, not only in Poland and other CEE countries, but also those who examined the capital structure choices in the developed economies. The same can be said about the link between size and leverage. We found our measure of leverage inversely dependent on profitability which confirms theoretical predictions of pecking order theory. Almost all studies conducted in Poland so far confirmed this direction of profitability influence on debt ratios ${ }^{123}$. Yet, despite the statistical significance of the factor, its explanatory power was relatively low in our study. Furthermore, we ascertained that profitability was insignificant in the pre-crisis model (we refer to this observation later in the article). Finally, in our study we used three measures of profitability (ROA, ROS and ROE), yet the empirical evidence showed that only ROE can be considered statistically significant factor in explaining leverage. This seems to confirm the supposition of Klapper, Sarria-Allende \& Sulla ${ }^{124}$ that ROE - as compared to other measures of profitability - may be more useful explanatory variable in considerably diversified samples of firms.

Similarly, we showed that size influences leverage in the positive way (bigger firms being more levered). Such observation is consistent with trade-off theory and was confirmed in almost all studies carried out in Poland. Finally, it must be noted that the observation is not only Polish or CEE phenomenon - it was also found in majority of foreign studies conducted in economies on various stages of the economic development (see Białek-Jaworska, Dzik \& Nehrebecka ${ }^{125}$ for comprehensive review of their results and Cwynar, Cwynar \& Dankiewicz ${ }^{126}$ for discussion on them).

Even though growth occurred to be insignificant in the model utilizing data from the entire period (2006-2011), it was found significant and positively related to leverage in the crisis period.

Other examined attributes were not included in the final models because of the collinearity (financial slack) or because they were estimated to be insignificant in explaining leverage (intangibility, non-debt tax shield and volatility). Such findings are in line with other studies (both conducted in Poland and abroad).

\footnotetext{
${ }^{121}$ M. Kouki \& H. Ben Said, Capital Structure Determinants: New Evidence from French Panel Data, "International Journal of Business and Management" 2012, Vol. 7, No. 1.

${ }^{122}$ See for example P. Hernádi \& M. Ormos, What Managers Think of Capital Structure and How They Act...; M. Szudejko, Analiza zależności pomiędzy branżą...

${ }^{123}$ Further discussion on the issue can be found A. Cwynar, W. Cwynar \& R. Dankiewicz, Studies of Firm...

${ }^{124}$ L. Klapper, V. Sarria-Allende \& V. Sulla, Small- and Medium...

${ }^{125}$ A. Białek-Jaworska, A. Dzik, \& N. Nehrebecka, Wplyw polityki monetarnej...

${ }^{126}$ A. Cwynar, W. Cwynar \& R. Dankiewicz, Studies of Firm Capital....
} 
Pre-crisis period (2006-2008) versus crisis period (2009-2011)

The subprime crisis and its secondary waves put the examination of the capital structure determinants in a new, interesting light. It is so because the origins as well as the consequences of the crisis are related to the financial market in general and the market for debt in particular. The nature and the properties of the crisis induce to formulate many curious research questions concerning the debt to equity ratio selection. In some countries the crisis led to credit rationing problems which potentially could shift the "normal" patterns regarding the way traditional firm-specific variables influence leverage.

The split of the entire period into two sub-periods in our study did not bring an evident change in the examined relationships. Tangibility preserved the status of the variable inversely related to leverage (in both sub-periods). We obtained also positive and almost the same coefficients before size in both models (pre-crisis and crisis, respectively). Interestingly, we noticed that profitability is statistically significant in explaining leverage only in the crisis period (yet, with low explanatory power). Moreover, growth joined the set of the significant factors in the crisis period with negative impact on leverage and low explanatory power.

It is intriguing that the set of statistically significant factors was found broader for crisis than for pre-crisis period. As mentioned before, profitability exhibited negative impact on leverage in our study, yet only in the crisis period. Knowing that the existing body of evidence concerning profitability confirms rather pecking order theory than trade-off theory predictions - not only in Poland, but also internationally - such findings can suggest that firms more readily turn to retained earnings as the financing option in worse times brought by the crisis. Another potential explanation can be the increase in the information asymmetry resulting from the crisis.

Positive dependence of leverage on growth only in the crisis period may be expounded in at least three ways. Firstly, the explanation can refer to short-term debt prevalence effect. The aggregate data for firms operating in Poland shows that short-term debt dominates in their liabilities structure ${ }^{127}$ and some authors hypothesize that even though leverage is negatively dependent on growth - since more severe information asymmetry imposed by rapid growth may lead to the increase in cost of long-term debt - it can be still positively related to short-term debt ${ }^{128}$. However, the justification is at most moderately convincing in the light of our findings since we found growth positively affecting leverage only in the crisis period. Secondly, it can be explained by "supply side phenomenon": the situation in which faster growing firms can get external financing easier ${ }^{129}$. Thirdly, it was noted that the crisis eventuated in evident decline in firms' profitability which - along with still positive growth rate - could force them to borrow more since the internal funds were not that available as before.

In search for the additional insight into the drives of leverage in the confronted sub-periods, we exchanged the best sets of explanatory variables between both models. Hence, in pre-crisis model we regressed the leverage on tangibility, growth, profitability and size, while tangibility and size were use as independent variables in the crisis period. Unfortunately, the models with exchanged explanatory variables did not add to what we knew before introducing them.

\footnotetext{
${ }^{127}$ J. Famielec, Struktura finansowania sektora przedsiębiorstw w Polsce w warunkach kryzysu, ,Z Zeszyty Naukowe Polskiego Towarzystwa Ekonomicznego" 2012, No. 12; A. Białek-Jaworska, A. Dzik \& N. Nehrebecka, Wplyw polityki monetarnej...

${ }^{128}$ M. Mateev, P. Poutziouris \& K. Ivanov, On the Determinants of SME Capital...

${ }^{129}$ L. Klapper, V. Sarria-Allende \& V. Sulla, Small- and Medium...
} 


\section{CONCLUSIONS}

Our findings confirm key relationships known from previous studies of other authors. We showed that profitability has got negative impact on leverage and size influences it positively, as in majority of other samples of firms examined in various countries, including Poland. However, some observations concerning profitability are novel and deserve further investigation. Firstly, we found ROE the only statistically significant metric of profitability out of three measures adopted in our models. Majority of the empirical capital structure studies utilized ROA as the proxy for profitability. Secondly, after splitting the entire period into pre-crisis and crisis intervals, we found that profitability is significant in explaining leverage only in the crisis sub-period.

We documented also negative relationship of tangibility with leverage. Previous studies showed that the sign of the relationship turns gradually from negative to positive along with the process of converging Polish economy to the developed ones, thus we expected rather positive link between tangibility and leverage than negative. We checked that it can't be explained by the hypothesis referring to the dominant share of short-term debt in the capital structures of firms operating in Poland.

Other key firm-specific factors known from the respective literature - such as nondebt tax shields, volatility and growth - were found irrelevant in explaining the equitydebt choice (except growth in crisis period). Additionally, even those variables which proved their significance in explaining leverage showed rather low explanatory power with few exceptions.

All of those findings mean that our study is inconclusive concerning the empirical verification of the predictions formulated on the ground of trade-off and pecking order theory, respectively. Positive link between size and leverage supports trade-off theory while negative relationship between profitability and leverage validates pecking order theory. Moreover, inverse dependence of leverage on tangibility is contrary to both theoretical schools.

Also, our models show that the latest global crisis did not result in a material shift in the way investigated firm-specific factors explain leverage despite that descriptive statistics report some changes in the financial performance of the sample firms (e.g. decline in profitability and asset growth rate).

\section{REFERENCES}

[1] Andrews D.W.K., Heteroscedasticity and Autocorrelation Consistent Covariance Matrix Estimation, "Econometrica" 1991, Vol. 59, No. 3, pp. 817-858.

[2] Bancel F., \& Mittoo U.R., The Determinants of Capital Structure Choice: A Survey of European Firms 2002, http://papers.ssrn.com/sol3/papers.cfm?abstract_id=299172.

[3] Barowicz M., Determinanty struktury kapitałowej przedsiębiorstwa. Podejście empiryczne, edu_Libri, Kraków 2015.

[4] Bauer P., Capital Structure of Listed Companies in Visegrad Countries, "Prague Economic Papers" 2004, Vol. 13, No. 2, pp. 159-175.

[5] Bevan A.A. \& Danbolt J., Dynamins in the Determinants of Capital Structure in the UK (Working paper 2000/9), http://papers.ssrn.com/sol3/papers.cfm?abstract_id=233551.

[6] Białek-Jaworska A., Dzik A. \& Nehrebecka N., Wpływ polityki monetarnej na źródła finansowania przedsiębiorstw w Polsce $w$ latach 1995-2012 (Materiaty i Studia nr 304), Narodowy Bank Polski, Warszawa 2014.

[7] Białek-Jaworska A., Nehrebecka N., Struktura kapitałowa przedsiębiorstw w świetle wyników badań, „Zeszyty Teoretyczne Rachunkowości” 2015, Vol. 81, No. 137, pp. 29-51. 
[8] Booth L., Aivazian V., Demirgüç-Kunt A. \& Maksimovic V., Capital Structures in Developing Countries, "The Journal of Finance" 2001, Vol. 56, No. 1, pp. 87-130.

[9] Campbell K. \& Jerzemowska M., Capital Structure Decisions Made by Companies in a Transitional Economy: the Case of Poland [in:] D. Zarzecki (Ed.), Financial Management. Objectives - Organization - Tools (pp. 51-76), Fundacja Rozwoju Rachunkowości w Polsce, Warszawa 2001.

[10] Chojnacka E., Struktura kapitalu spótek akcyjnych w Polsce w świetle teorii hierarchii źródel finansowania, CeDeWu, Warszawa 2012.

[11] Ciołek D. \& Koralun-Bereźnicka J., Czy wielkość przedsiębiorstwa różnicuje siłę oddziaływania czynników krajowych i branżowych na strukturę kapitalu? „Bank i Kredyt” 2014, Vol. 45, No. 3, pp. 291-310.

[12] Cornelli F., Portes R. \& Schaffer M., Financial Structure of Firms in the CEECs [in:] O. Bouin, F. Coricelli, \& F. Lemoine (Eds.), Different Paths to a Market Economy. China and European Economies in Transition (pp. 171-197), OECD 1998, http://www.keepeek.com/Digital-Asset-Management/oecd/development/different-paths-to-amarket-economy-china-and-european-economies-in-transition_9789264163010-en\#page183.

[13] Cwynar A., Cwynar W. \& Dankiewicz R., Studies of Firm Capital Structure Determinants in Poland: An Integrative Review, e-Finanse 2015, Vol. 11, No. 4, pp. 1-22.

[14] De Haas R. \& Peeters M., The Dynamic Adjustment Towards Target Capital Structures of Firms in Transition Economies, "Economics of Transition" 2006, Vol. 14, No. 1, pp. 133-169.

[15] De Jong A., Kabir R. \& Nguyen T.T., Capital Structure Around the World: The Roles of Firm- and Country-Specific Determinants, "Journal of Banking and Finance" 2008, Vol. 32, No. 9, pp. 1957-1969.

[16] Delcoure N., The Determinants of Capital Structure in Transitional Economies, "International Review of Economics and Finance" 2007, Vol. 16, No. 3, pp. 400-415.

[17] Demirgüç-Kunt A. \& Maksimovic V., Institutions, Financial Markets, and Firm Debt Maturity, "Journal of Financial Economics" 1999, Vol. 54, No. 3, pp. 295-336.

[18] Demirgüç-Kunt A. \& Maksimovic V., Stock Market Development and Firm Financing Choices, "World Bank Economic Review" 1996, Vol. 10, No. 2, pp. 341-369.

[19] Dević A. \& Krstić B., Comparatible Analysis of the Capital Structure Determinants in Polish and Hungarian Enterprises - Empirical Study, Facta Universitatis (Series: Economics and Organization), 2001,Vol. 1, No. 9, pp. 85-100.

[20] Donaldson G., Corporate Debt Capacity: A Study of Corporate Debt Policy and the Determination of Corporate Debt Capacity, Harvard School of Business Administration, Boston 1961.

[21] Driscoll J. \& Kraay A., Consistent Covariance Matrix Estimation With Spatially Dependent Panel Data, "The Review of Economics and Statistics" 1998, Vol. 80, No. 4, pp. 549-560.

[22] Duliniec A., Struktura i koszt kapitalu w przedsiębiorstwie, PWN, Warszawa 1998.

[23] Famielec J., Struktura finansowania sektora przedsiębiorstw w Polsce w warunkach kryzysu, „Zeszyty Naukowe Polskiego Towarzystwa Ekonomicznego” 2012, No. 12, pp. 173-184.

[24] Frank M.Z. \& Goyal V.K., Trade-off and Pecking Order Theories of Debt (Working paper) 2005, http://www.tc.umn.edu/ murra280/WorkingPapers/Survey.pdf.

[25] Frąckowiak W., Gryglewicz S., Stobiecki P., Stradomski M. \& Szyszka A., Polityka ksztattowania struktury kapitału w polskich przedsiębiorstwach na tle wybranych krajów Unii Europejskiej [in:] J. Ostaszewski (Ed.), Finanse przedsiębiorstwa (pp. 153-172), Oficyna Wydawnicza SGH, Warszawa 2005.

[26] Gajdka J., Teorie struktury kapitalu $i$ ich aplikacja $w$ warunkach polskich, Wydawnictwo Uniwersytetu Łódzkiego, Łódź 2002.

[27] Graham J.R., \& Harvey C.R., How Do CFOs Make Capital Budgeting and Capital Structure Decisions?, "Journal of Applied Corporate Finance" 2002, Vol. 15, No. 1, pp. 8-23.

[28] Hall G., Hutchinson P., \& Michaelas N., East and West: Differences in SME Capital Structure Between Former Soviet-Bloc and Non Soviet-Bloc European Countries 2006, http://www.gregoriae.com/dmdocuments/m56.pdf. 
[29] Hamrol M. \& Sieczko J., Czynniki kształtujace strukturę kapitału polskich spótek giełdowych, Prace i Materiały Wydziału Zarządzania Uniwersytetu Gdańskiego, 2006, No. 1, pp. 127-141.

[30] Harris M. \& Raviv A., The Theory of Capital Structure, "The Journal of Finance" 1991, Vol. 46, No. 1, pp. 297-355.

[31] Hellwig Z., On the optimal choice of predictors, in: Z. Gostkowski (Ed.), Toward a system of quantitative indicators of components of human resources development (pp. 171-197) 1968, UNESCO, Paris, http://unesdoc.unesco.org/images/0015/001585/158559eb.pdf.

[32] Hernádi P. \& Ormos M., Capital Structure and Its Choice in Central and Eastern Europe, Acta Oeconomica 2012, Vol. 62, No. 2, pp. 229-263.

[33] Hernádi P. \& Ormos M., What Managers Think of Capital Structure and How They Act: Evidence from Central and Eastern Europe, "Baltic Journal of Economics" 2012, Vol. 12, No. 2, pp. 47-71.

[34] Hussain Q, \& Nivorozhkin E., The Capital Structure of Listed Companies in Poland 1997 (IMF Working Paper No WP/97/1975), http://www.imf.org/external/pubs/ft/wp/wp97175.pdf.

[35] Jędrzejczak-Gas J., Struktura kapitału w matych i średnich przedsiębiorstwach, „Zeszyty Naukowe Uniwersytetu Szczecińskiego. Finanse, Rynki Finansowe, Ubezpieczenia” 2013, Vol. 766, No. 62, pp. 583-593.

[36] Jõeveer K., Sources of Capital Structure: Evidence from Transition Countries (Bank of Estonia Working Paper No 2/2006), 2006, https://www.eestipank.ee/sites/.../files/.../wp_206.pdf.

[37] Kędzior M., Capital Structure in EU Selected Countries - Micro and Macro Determinants, “Argumenta Oeconomica" 2012, Vol. 1, No. 28, pp. 69-117.

[38] Kirch G., Mateus C. \& Terra P.R.S., Country Governance Structure and Financial Development as Determinants of Firms' Capital Structure, “Journal of Money, Investment and Banking” 2012, No. 26, pp. 6-24, http://papers.ssrn.com/sol3/papers.cfm?abstract_id=2353663\&download=yes.

[39] Klapper L., Sarria-Allende V. \& Sulla V., Small- and Medium-Size Enterprise Financing in Eastern Europe (World Bank Policy Research Working Paper 2001, No. 2933), http://www1.worldbank.org/finance/assets/images/2933.pdf.

[40] Korajczyk R.A. \& Levy A., Capital Structure Choice: Macroeconomic Conditions and Financial Constraints, "Journal of Financial Economics" 2003, Vol. 68, No. 1, pp. 75-109.

[41] Kouki M., \& Ben Said H. (2012), Capital Structure Determinants: New Evidence from French Panel Data, "International Journal of Business and Management" 2012, Vol. 7, No. 1, pp. 214-229.

[42] Łuczka T., Struktura kapitału w mikro- i matych przedsiębiorstwach, „Ekonomika i Organizacja Przedsiębiorstwa" 2006, special issue, pp. 70-73.

[43] Mateev M., Poutziouris P. \& Ivanov K., On the Determinants of SME Capital Structure in Central and Eastern Europe: A Dynamic Panel Analysis, "Research in International Business and Finance" 2013, Vol. 27, No. 1, pp. 28-51.

[44] Mateus C., Terra P.R.S., Leverage and Maturity Structure of Debt in Emerging Markets, "Journal of Mathematical Finance" 2013, Vol. 3, No. 3A, pp. 46-59, http://papers.ssrn.com/sol3/papers.cfm?abstract_id=2353638.

[45] Modigliani F. \& Miller M.H., The Cost of Capital, Corporation Finance, and the Theory of Investment, "American Economic Review" 1958, Vol. 48, No. 3, pp. 261-297.

[46] Mokhova N. \& Zinecker M., The Determinants of Capital Structure: The Evidence from the European Union, Acta Universitatis Agriculturae Et Silviculturae Mendelianae Brunensis 2013, Vol. 282, No. 7, pp. 2533-2546.

[47] Mostarac E. \& Petrovic S., Determinants of Capital Structure of Croatian Enterprises Before and During the Financial Crisis, "UTMS Journal of Economics" 2013, Vol. 4, No. 2, pp. $153-162$.

[48] Myers S. \& Majluf N., Corporate Financing and Investment Decisions When Firms Have Information Investors Do Not Have, "Journal of Financial Economics" 1984, Vol. 13, No. 2, pp. 187-221. 
[49] Prędkiewicz K. \& Prędkiewicz P., Wybrane determinanty struktury kapitału mikro, małych $i$ średnich przedsiębiorstw $w$ Polsce, , Zeszyty Naukowe Uniwersytetu Szczecińskiego. Finanse, Rynki Finansowe, Ubezpieczenia” 2014, Vol. 802, No. 65, pp. 829-842.

[50] Rajan R.G. \& Zingales L., What Do We Know about Capital Structure? Some Evidence from International Data, "The Journal of Finance" 1995, Vol. 50, No. 5, pp. 1421-1460.

[51] Shamshur A., Access to Capital and Capital Structure of the Firm (CERGE-EI Working Paper 2010, No 429), https://www.cerge-ei.cz/pdf/wp/Wp429.pdf.

[52] Szudejko M., Analiza zależności pomiędzy branża a struktura kapitału przedsiębiorstwa na podstawie wyników finansowych polskich spótek giełdowych, ,Zeszyty Naukowe Uniwersytetu Szczecińskiego. Finanse, Rynki Finansowe, Ubezpieczenia” 2013, Vol. 766, No. 62, pp. 701-711.

[53] Titman S. \& Wessels R., The Determinants of Capital Structure Choice, "The Journal of Finance" 1988, Vol. 43, No. 1, pp. 1-19.

[54] Weill L., Determinants of Leverage and Access to Credit: Evidence on Western and Eastern Europe Countries 2002, http://www.researchgate.net/publication/253293146_ Determinants_of_Leverage_and_Access_to_Credit_Evidence_on_Western_and_Eastern_Europe_countries

[55] Weill L., What Determines Leverage in Transition Countries? "Czech Journal of Economics and Finance" 2004, Vol. 54, No. 5-6, pp. 234-242.

[56] Wooldridge J.M., Introductory Econometrics: A Modern Approach, South-Western College Pub, Mason 2013.

[57] Wypych M., Równowaga finansowa przedsiębiorstw przemysłowych w okresie spowolnienia finansowego, ,Zeszyty Naukowe Politechniki Śląskiej (seria Organizacja i Zarządzanie)” 2014, Vol. 73, No. 1919, pp. 665-672.

[58] Zeileis A., Econometric Computing with HC and HAC Covariance Matrix Estimators, "Journal of Statistical Software" 2004, Vol. 11, No. 10, pp. 1-17.

\section{DETERMINANTY STRUKTURY KAPITALU PRZEDSIĘBIORSTWA W CZASIE OSTATNIEGO GLOBALNEGO KRYZYSU: PRZYPADEK POLSKI}

Kształtowanie struktur kapitałowych w przedsiębiorstwach, a zwłaszcza identyfikacja czynników decydujących o wyborach struktur kapitałowych, to wciąż zagadnienie będące wyzwaniem badawczym, domagające się dalszych studiów empirycznych. Niedawny globalny kryzys postawił to zagadnienie w nowym świetle, ponieważ zadłużenie stało się jednym z najbardziej palących problemów kryzysowego okresu. Wykorzystując dane panelowe i analizę regresji wielorakiej zbadaliśmy zróżnicowaną próbę ponad 4000 publicznych i niepublicznych firm działających w Polsce w okresie 2006-2011 w celu poznania stopnia, w jakim kluczowe, znane $\mathrm{z}$ teorii czynniki specyficzne dla badanych przedsiębiorstw wyjaśniają ich struktury kapitałowe. W szczególności badanie miało na celu zbadanie, czy kryzysowe warunki gospodarowania miały wpływ na analizowane w modelach zależności. Otrzymane wyniki potwierdziły ustalenia wcześniejszych badaczy dotyczące wpływu rentowności i wielkości przedsiębiorstwa na udział długu w strukturze kapitałowej. Wyniki te nie potwierdziły jednak jednoznacznie żadnej z klasycznych teorii struktury kapitału przedsiębiorstwa - ani teorii substytucji, ani teorii hierarchii źródeł finansowania. Pokazały one natomiast, że niedawny globalny kryzys nie doprowadził do istotnych zmian w strukturach kapitałowych badanych przedsiębiorstw. Niektóre z wyników prezentowanego badania mogą mieć znaczenie dla praktyki biznesowej, nakreślając kierunki zmian w instytucjonalnym otoczeniu przedsiębiorstw a także sugerując kształt polityki kreującej to otoczenie. 


\section{APPENDIX}

Table 1. The representation of the sectors in the sample

\begin{tabular}{|l|c|}
\hline Sector & $\begin{array}{c}\text { Number of } \\
\text { firms }\end{array}$ \\
\hline Agriculture, forestry, hunting and fishing & 70 \\
\hline Mining and quarrying & 36 \\
\hline Manufacturing & 1199 \\
\hline Electricity, gas, warm water, steam and air for A/C manufacturing and supply & 121 \\
\hline Water supply and recycling & 192 \\
\hline Construction & 316 \\
\hline Wholesale and retail trade; repair of motor vehicles and motorcycles & 781 \\
\hline Transport and storage & 176 \\
\hline Hotels and restaurants & 42 \\
\hline Information and communication & 110 \\
\hline Real estate services & 225 \\
\hline Profesional, scientific and technical activities & 181 \\
\hline Administration services and supporting activities & 68 \\
\hline Public administration and defense; compulsory social security & 7 \\
\hline Education & 83 \\
\hline Health and social work & 127 \\
\hline Recreational, cultural and sporting activities & 39 \\
\hline Other services & 11 \\
\hline Total & $\mathbf{3 7 8 4}$ \\
\hline Source: own work & 39 \\
\hline
\end{tabular}

Source: own work.

Table 2. Dependent and independent variables used in the models

\begin{tabular}{|c|c|c|c|c|c|c|c|}
\hline DEPEND- & \multicolumn{7}{|c|}{ INDEPENDENT VARIABLES (firm-specific quantitative attributes) } \\
\hline Leverage & Asset structure & $\begin{array}{l}\text { Non-debt } \\
\text { tax shield }\end{array}$ & Growth & Profitability & $\begin{array}{c}\text { Financial } \\
\text { slack }\end{array}$ & Size & $\begin{array}{l}\text { Vola- } \\
\text { tility }\end{array}$ \\
\hline $\begin{array}{c}\mathrm{Y}-\text { total } \\
\text { liabilities / } \\
\text { total asets }\end{array}$ & $\begin{array}{c}\text { X1 (intangibil- } \\
\text { ity) - intangible } \\
\text { assets / total } \\
\text { assets } \\
\text { X2 (tangibility) } \\
\text { - (gross plant \& } \\
\text { equipment + } \\
\text { inventory) / } \\
\text { total assets }\end{array}$ & $\begin{array}{c}\mathrm{X} 3- \\
\text { deprecia- } \\
\text { tion / } \\
\text { total } \\
\text { assets }\end{array}$ & $\begin{array}{c}\mathrm{X} 4-\% \\
\text { change in } \\
\text { total } \\
\text { assets }\end{array}$ & $\begin{array}{c}\text { X5 (ROA) - } \\
\text { EBIT / total } \\
\text { assets } \\
\text { X6 (ROS) - } \\
\text { net profit / } \\
\text { sales revenue } \\
\text { X7 (ROE) - } \\
\text { net profit / } \\
\text { equity }\end{array}$ & $\begin{array}{c}\mathrm{X} 8- \\
\text { (cash + } \\
\text { equiva- } \\
\text { lents) / } \\
\text { total } \\
\text { assets }\end{array}$ & $\begin{array}{c}\mathrm{X} 9- \\
\text { natural } \\
\text { loga- } \\
\text { rithm } \\
\text { of sales } \\
\text { reve- } \\
\text { nue }\end{array}$ & $\begin{array}{l}\text { X10- } \\
\text { stand- } \\
\text { ard } \\
\text { devia- } \\
\text { tion of } \\
\text { EBIT }\end{array}$ \\
\hline
\end{tabular}

Source: own work. 
Table 3. Descriptive statistics of the variables selected to the final multiple factor regression models

\begin{tabular}{|c|c|c|c|c|c|}
\hline & $Y$ & $X 2$ & $X 4$ & $X 7$ & $X 9$ \\
\hline \multicolumn{6}{|c|}{2006} \\
\hline Mean & 0,4488 & 0,5662 & 0,6935 & 0,1019 & 17,41 \\
\hline Median & 0,4463 & 0,6099 & 0,0856 & 0,0968 & 17,38 \\
\hline$S D$ & 0,2486 & 0,2557 & 19,7120 & 2,0029 & 1,32 \\
\hline \multicolumn{6}{|c|}{2007} \\
\hline Mean & 0,4379 & 0,5727 & 0,7168 & 0,1335 & 17,52 \\
\hline Median & 0,4324 & 0,6180 & 0,0832 & 0,1089 & 17,48 \\
\hline$S D$ & 0,2427 & 0,2575 & 26,9510 & 0,8413 & 1,33 \\
\hline \multicolumn{6}{|c|}{2008} \\
\hline Mean & 0,4401 & 0,5751 & 0,8817 & $-0,0086$ & 17,58 \\
\hline Median & 0,4304 & 0,6284 & 0,0504 & 0,0698 & 17,55 \\
\hline$S D$ & 0,2451 & 0,2594 & 27,2841 & 3,2139 & 1,30 \\
\hline \multicolumn{6}{|c|}{2009} \\
\hline Mean & 0,4221 & 0,5689 & 0,0663 & 0,0487 & 17,57 \\
\hline Median & 0,4068 & 0,6154 & 0,0115 & 0,0669 & 17,55 \\
\hline$S D$ & 0,2392 & 0,2605 & 1,3899 & 1,4472 & 1,29 \\
\hline \multicolumn{6}{|c|}{2010} \\
\hline Mean & 0,4275 & 0,5621 & 0,0915 & 0,0362 & 17,60 \\
\hline Median & 0,4146 & 0,6096 & 0,0368 & 0,0656 & 17,56 \\
\hline$S D$ & 0,2375 & 0,2601 & 0,5713 & 1,4335 & 1,34 \\
\hline \multicolumn{6}{|c|}{2011} \\
\hline Mean & 0,4399 & 0,5544 & 0,0956 & 0,0281 & 17,66 \\
\hline Median & 0,4315 & 0,5989 & 0,0478 & 0,0542 & 17,64 \\
\hline$S D$ & 0,2426 & 0,2637 & 0,2833 & 0,7253 & 1,38 \\
\hline \multicolumn{6}{|c|}{ 2006-2011 } \\
\hline Mean & 0,4360 & 0,5666 & 0,4242 & 0,0566 & 17,56 \\
\hline Median & 0,4267 & 0,6132 & 0,0501 & $\mathbf{0 , 0 7 5 7}$ & 17,52 \\
\hline$S D$ & 0,2428 & 0,2596 & 17,6162 & $\mathbf{1 , 8 1 3 5}$ & 1,33 \\
\hline
\end{tabular}

Source: own work. 
Table 4. 2006-2011 model: correlation matrix

\begin{tabular}{|c|c|c|c|c|c|c|c|c|c|c|}
\hline & $\boldsymbol{X}_{\boldsymbol{1}}$ & $\boldsymbol{X}_{\mathbf{2}}$ & $\boldsymbol{X}_{\mathbf{3}}$ & $\boldsymbol{X}_{\mathbf{4}}$ & $\boldsymbol{X}_{\mathbf{5}}$ & $\boldsymbol{X}_{\mathbf{6}}$ & $\boldsymbol{X}_{\mathbf{7}}$ & $\boldsymbol{X}_{\boldsymbol{8}}$ & $\boldsymbol{X}_{\mathbf{9}}$ & $\boldsymbol{X}_{\mathbf{1 0}}$ \\
\hline $\boldsymbol{X}_{\boldsymbol{1}}$ & 1 & & & & & & & & & \\
\hline $\boldsymbol{X}_{\mathbf{2}}$ & $-0,137$ & 1 & & & & & & & & \\
\hline $\boldsymbol{X}_{\boldsymbol{3}}$ & 0,011 & 0,037 & 1 & & & & & & & \\
\hline $\boldsymbol{X}_{\mathbf{4}}$ & 0,027 & $-0,001$ & $-0,002$ & 1 & & & & & & \\
\hline $\boldsymbol{X}_{\boldsymbol{5}}$ & $-0,008$ & $-0,217$ & $-0,004$ & 0,002 & 1 & & & & & \\
\hline $\boldsymbol{X}_{\boldsymbol{6}}$ & $-0,001$ & 0,015 & 0,001 & 0,000 & 0,009 & 1 & & & & \\
\hline $\boldsymbol{X}_{\boldsymbol{7}}$ & $-0,005$ & $-0,032$ & $-0,004$ & 0,001 & 0,178 & 0,000 & 1 & & & \\
\hline $\boldsymbol{X}_{\boldsymbol{8}}$ & $-0,037$ & $-0,496$ & $-0,007$ & $-0,005$ & 0,148 & 0,009 & 0,035 & 1 & & \\
\hline $\boldsymbol{X}_{\boldsymbol{9}}$ & 0,053 & $-0,092$ & 0,000 & 0,029 & 0,207 & $-0,047$ & 0,024 & $-0,118$ & 1 & \\
\hline $\boldsymbol{X}_{\boldsymbol{1 0}}$ & 0,004 & $-0,010$ & $-0,002$ & 0,234 & 0,006 & 0,001 & 0,002 & 0,004 & 0,072 & 1 \\
\hline
\end{tabular}

Source: own work.

Table 5. 2006-2011 model: single factor regression results

\begin{tabular}{|c|c|c|c|c|c|c|c|c|c|c|}
\hline & $\boldsymbol{X}_{\boldsymbol{1}}$ & $\boldsymbol{X}_{\mathbf{2}}$ & $\boldsymbol{X}_{\mathbf{3}}$ & $\boldsymbol{X}_{\mathbf{4}}$ & $\boldsymbol{X}_{\mathbf{5}}$ & $\boldsymbol{X}_{\mathbf{6}}$ & $\boldsymbol{X}_{\mathbf{7}}$ & $\boldsymbol{X}_{\boldsymbol{8}}$ & $\boldsymbol{X}_{\mathbf{9}}$ & $\boldsymbol{X}_{\mathbf{1 0}}$ \\
\hline $\begin{array}{c}\text { Correlation } \\
\text { coefficient r }\end{array}$ & 0,0237 & $-0,1465$ & $-0,0001$ & 0,0000 & $-0,0270$ & 0,0040 & $-0,0543$ & $-0,2220$ & 0,2859 & $-0,0020$ \\
\hline $\begin{array}{c}\text { Determinan } \\
\text { tion coeffi- } \\
\text { cient R }\end{array}$ & 0,0006 & 0,0215 & 0 & 0 & 0,0007 & 0 & 0,0029 & 0,0493 & 0,0817 & 0 \\
\hline $\begin{array}{c}\text { Standard } \\
\text { error s }\end{array}$ & 0,2427 & 0,2401 & 0,2428 & 0,2428 & 0,2427 & 0,2428 & 0,2424 & 0,2367 & 0,2326 & 0,2428 \\
\hline $\boldsymbol{\alpha}_{\mathbf{0}}$ & 0,4348 & 0,5137 & 0,436 & 0,436 & 0,44 & 0,436 & 0,4364 & 0,4813 & $-0,4815$ & 0,4361 \\
\hline $\boldsymbol{\alpha}_{\mathbf{1}}$ & 0,1369 & $-0,137$ & $-0,0001$ & 0 & $-0,0537$ & 0 & $-0,0073$ & $-0,3480$ & 0,0523 & 0 \\
\hline p-value & 0,0004 & 0 & 0,9936 & 0,9993 & 0 & 0,5449 & 0 & 0 & 0 & 0,7594 \\
\hline
\end{tabular}

work

Table 6. 2006-2011 model: multiple factor regression model results, pooled OLS model applied

\begin{tabular}{|c|c|c|c|c|c|}
\hline \multicolumn{6}{|c|}{$Y=-0,3844-0,1154 \cdot X_{2}-0,0087 \cdot X_{7}+0,0505 \cdot X_{9}$} \\
\hline $\begin{array}{c}\text { Multiple factor regression model } \\
\text { Determination coefficient } \\
\boldsymbol{R}^{2}\end{array}$ & $\mathbf{0 , 1 0 0 5}$ & $\boldsymbol{\alpha}_{\boldsymbol{0}}$ & $\boldsymbol{\alpha}_{2}$ & $\boldsymbol{\alpha}_{7}$ & $\boldsymbol{\alpha}_{9}$ \\
\hline $\boldsymbol{\alpha}$ & & $-0,3844$ & $-0,1154$ & $-0,0087$ & 0,0505 \\
\hline Standard errors & $\mathbf{0 , 2 3 0 2}$ & 0,0209 & 0,0059 & 0,0008 & 0,0012 \\
\hline $\boldsymbol{p}$-value & $\mathbf{0}$ & 0 & 0 & 0 & 0 \\
\hline HAC standard errors* & & 0,0284 & 0,0081 & 0,0024 & 0,0016 \\
\hline HAC p-value z-test ${ }^{* *}$ & & 0 & 0 & 0 & 0 \\
\hline HAC p-value t-test*** & & 0 & 0 & 0 & 0 \\
\hline
\end{tabular}

$*, * *, * * *$ - to tackle errors serial correlation and heteroscedasticity HAC covariance matrix was estimated.

Source: own work.

Table 7. Pre-crisis model: correlation matrix 


\begin{tabular}{|c|c|c|c|c|c|c|c|c|c|c|}
\hline & $X_{I}$ & $X_{2}$ & $X_{3}$ & $X_{4}$ & $X_{5}$ & $X_{6}$ & $X_{7}$ & $X_{8}$ & $X_{9}$ & $X_{10}$ \\
\hline$X_{1}$ & 1 & & & & & & & & & \\
\hline$X_{2}$ & $-0,133$ & 1 & & & & & & & & \\
\hline$X_{3}$ & 0,078 & 0,208 & 1 & & & & & & & \\
\hline$X_{4}$ & 0,037 & $-0,001$ & $-0,014$ & 1 & & & & & & \\
\hline$X_{5}$ & $-0,020$ & $-0,243$ & $-0,054$ & $-0,002$ & 1 & & & & & \\
\hline$X_{6}$ & $-0,001$ & 0,023 & 0,012 & 0,001 & 0,011 & 1 & & & & \\
\hline$X_{7}$ & $-0,012$ & $-0,028$ & $-0,016$ & 0,001 & 0,148 & 0,000 & 1 & & & \\
\hline$X_{8}$ & $-0,040$ & $-0,499$ & $-0,075$ & $-0,008$ & 0,164 & 0,012 & 0,028 & 1 & & \\
\hline$X_{9}$ & 0,057 & $-0,111$ & $-0,016$ & 0,041 & 0,183 & $-0,016$ & 0,015 & $-0,113$ & 1 & \\
\hline$X_{10}$ & 0,005 & $-0,004$ & $-0,011$ & 0,332 & 0,012 & 0,001 & 0,003 & 0,004 & 0,083 & 1 \\
\hline
\end{tabular}

Source: own work.

Table 8. Pre-crisis model: single factor regression results

\begin{tabular}{|c|c|c|c|c|c|c|c|c|c|c|c|}
\hline & $\boldsymbol{X}_{\boldsymbol{1}}$ & $\boldsymbol{X}_{\mathbf{2}}$ & $\boldsymbol{X}_{\mathbf{3}}$ & $\boldsymbol{X}_{\mathbf{4}}$ & $\boldsymbol{X}_{\mathbf{5}}$ & $\boldsymbol{X}_{\mathbf{6}}$ & $\boldsymbol{X}_{\mathbf{7}}$ & $\boldsymbol{X}_{\boldsymbol{8}}$ & $\boldsymbol{X}_{\boldsymbol{9}}$ & $\boldsymbol{X}_{\boldsymbol{1 0}}$ \\
\hline $\begin{array}{c}\text { Correlation } \\
\text { coefficient } \boldsymbol{r}\end{array}$ & 0,0313 & $-0,1845$ & $-0,0072$ & $-0,0024$ & $-0,0180$ & 0,0068 & $-0,0425$ & $-0,2022$ & 0,2894 & 0,0018 \\
\hline $\begin{array}{c}\text { Determinan- } \\
\text { tion coefficient } \\
\boldsymbol{R}^{\mathbf{2}}\end{array}$ & 0,001 & 0,0341 & 0,0001 & 0 & 0,0003 & 0 & 0,0018 & 0,0409 & 0,0409 & 0,0838 \\
\hline $\begin{array}{c}\text { Standard error } \\
\boldsymbol{s}\end{array}$ & 0,2454 & 0,2413 & 0,2455 & 0,2455 & 0,2455 & 0,2455 & 0,2453 & 0,2404 & 0,2404 & 0,235 \\
\hline $\boldsymbol{\alpha}_{\boldsymbol{0}}$ & 0,4406 & 0,5427 & 0,4443 & 0,4423 & 0,4452 & 0,4423 & 0,4426 & 0,4838 & 0,4838 & $-0,5025$ \\
\hline $\boldsymbol{\alpha}_{\boldsymbol{1}}$ & 0,1909 & $-0,1759$ & $-0,0444$ & 0 & $-0,0347$ & 0 & $-0,0047$ & $-0,3251$ & $-0,3251$ & 0,054 \\
\hline $\boldsymbol{p}$-value & 0,0008 & 0 & 0,443 & 0,7999 & 0,0548 & 0,4658 & 0 & 0 & 0 & 0 \\
\hline
\end{tabular}

Source: own work.

Table 9. Pre-crisis model: multiple factor regression model results, pooled OLS model applied

\begin{tabular}{|c|c|c|c|c|}
\hline \multicolumn{5}{|c|}{$Y=-0,3626-0,1417 \cdot X_{2}+0,0508 \cdot X_{9}$} \\
\hline \multicolumn{2}{|c|}{ Multiple factor regression model } & \multirow[t]{2}{*}{$\alpha_{0}$} & \multirow[t]{2}{*}{$\alpha_{2}$} & \multirow[t]{2}{*}{$\alpha_{9}$} \\
\hline Determination coefficient $R^{2}$ & $\begin{array}{c}\mathbf{0 , 1 0 7} \\
\mathbf{3}\end{array}$ & & & \\
\hline$\alpha$ & & $-0,3626$ & $-0,1471$ & 0,0508 \\
\hline Standard errors & $\mathbf{0 , 2 3 2}$ & 0,0301 & 0,0085 & 0,0017 \\
\hline p-value & $\mathbf{0}$ & 0 & 0 & 0 \\
\hline HAC standard errors* & & 0,0437 & 0,0115 & 0,0024 \\
\hline HAC p-value z-test** & & 0 & 0 & 0 \\
\hline HAC p-value t-test ${ }^{* * * *}$ & & 0 & 0 & 0 \\
\hline
\end{tabular}

$*, * *, * * *-$ to tackle errors serial correlation and heteroscedasticity HAC covariance matrix was estimated.

Source: own work.

Table 10. Crisis model: correlation matrix 


\begin{tabular}{|c|c|c|c|c|c|c|c|c|c|c|}
\hline & $\boldsymbol{X}_{\boldsymbol{1}}$ & $\boldsymbol{X}_{\mathbf{2}}$ & $\boldsymbol{X}_{\mathbf{3}}$ & $\boldsymbol{X}_{\boldsymbol{4}}$ & $\boldsymbol{X}_{\mathbf{5}}$ & $\boldsymbol{X}_{\boldsymbol{6}}$ & $\boldsymbol{X}_{\boldsymbol{7}}$ & $\boldsymbol{X}_{\boldsymbol{8}}$ & $\boldsymbol{X}_{\boldsymbol{9}}$ & $\boldsymbol{X}_{\boldsymbol{1 0}}$ \\
\hline $\boldsymbol{X}_{\boldsymbol{1}}$ & 1 & & & & & & & & & \\
\hline $\boldsymbol{X}_{\boldsymbol{2}}$ & $-0,141$ & 1 & & & & & & & & \\
\hline $\boldsymbol{X}_{\boldsymbol{3}}$ & 0,006 & 0,028 & 1 & & & & & & & \\
\hline $\boldsymbol{X}_{\boldsymbol{4}}$ & 0,067 & $-0,045$ & $-0,005$ & 1 & & & & & & \\
\hline $\boldsymbol{X}_{\boldsymbol{5}}$ & 0,004 & $-0,196$ & 0,002 & 0,054 & 1 & & & & & \\
\hline $\boldsymbol{X}_{\boldsymbol{6}}$ & $-0,002$ & $-0,009$ & 0,000 & 0,004 & 0,021 & 1 & & & & \\
\hline $\boldsymbol{X}_{\boldsymbol{7}}$ & 0,005 & $-0,043$ & $-0,004$ & 0,020 & 0,251 & 0,007 & 1 & & & \\
\hline $\boldsymbol{X}_{\boldsymbol{8}}$ & $-0,034$ & $-0,492$ & $-0,002$ & 0,016 & 0,135 & 0,005 & 0,050 & 1 & & \\
\hline $\boldsymbol{X}_{\boldsymbol{9}}$ & 0,048 & $-0,071$ & 0,002 & 0,012 & 0,241 & $-0,005$ & 0,043 & $-0,120$ & 1 & \\
\hline $\boldsymbol{X}_{\boldsymbol{1 0}}$ & 0,003 & $-0,016$ & $-0,002$ & 0,001 & $-0,002$ & 0,003 & 0,000 & 0,003 & 0,060 & 1 \\
\hline
\end{tabular}

Source: own work.

Table 11. Crisis model: single factor regression results

\begin{tabular}{|c|c|c|c|c|c|c|c|c|c|c|}
\hline & $\boldsymbol{X}_{\boldsymbol{I}}$ & $\boldsymbol{X}_{\boldsymbol{2}}$ & $\boldsymbol{X}_{\boldsymbol{3}}$ & $\boldsymbol{X}_{\boldsymbol{4}}$ & $\boldsymbol{X}_{\boldsymbol{5}}$ & $\boldsymbol{X}_{\boldsymbol{6}}$ & $\boldsymbol{X}_{\boldsymbol{7}}$ & $\boldsymbol{X}_{\boldsymbol{8}}$ & $\boldsymbol{X}_{\boldsymbol{9}}$ & $\boldsymbol{X}_{\boldsymbol{1 0}}$ \\
\hline $\begin{array}{c}\text { Correlation } \\
\text { coefficient } \boldsymbol{r}\end{array}$ & 0,0166 & $-0,1092$ & 0,0009 & 0,0485 & $-0,0429$ & $-0,0090$ & $-0,0823$ & $-0,2414$ & 0,2852 & $-0,0060$ \\
\hline $\begin{array}{c}\text { Determinan- } \\
\text { tion coeffi- } \\
\text { cient } \boldsymbol{R}^{2}\end{array}$ & 0,0003 & 0,0119 & 0,0000 & 0,0024 & 0,0018 & 0,0001 & 0,0068 & 0,0583 & 0,0813 & 0,0000 \\
\hline $\begin{array}{c}\text { Standard } \\
\text { error } \boldsymbol{s}\end{array}$ & 0,2398 & 0,2384 & 0,2398 & 0,2396 & 0,2396 & 0,2398 & 0,2390 & 0,2328 & 0,2299 & 0,2398 \\
\hline $\boldsymbol{\alpha}_{\boldsymbol{0}}$ & 0,4290 & 0,4861 & 0,4298 & 0,4287 & 0,4353 & 0,4298 & 0,4304 & 0,4786 & $-0,4707$ & 0,4299 \\
\hline $\boldsymbol{\alpha}_{\boldsymbol{1}}$ & 0,0914 & $-0,1002$ & 0,0007 & 0,0132 & $-0,0899$ & $-0,0004$ & $-0,0158$ & $-0,3687$ & 0,0511 & 0,0000 \\
\hline $\boldsymbol{p}$-value & 0,0765 & 0,0000 & 0,9205 & 0,0000 & 0,0000 & 0,3358 & 0,0000 & 0,0000 & 0,0000 & 0,5232 \\
\hline
\end{tabular}

Source: own work.

Table 12. Crisis model: multiple factor regression model results, pooled OLS model applied

\begin{tabular}{|c|c|c|c|c|c|c|}
\hline \multicolumn{7}{|c|}{$Y=-0,4152-0,0841 \cdot X_{2}+0,0117 \cdot X_{4}-0,0191 \cdot X_{7}+0,0507 \cdot X_{9}$} \\
\hline Multiple factor & ion model & $\alpha_{0}$ & $\alpha_{2}$ & $\alpha_{4}$ & $\alpha_{7}$ & $\alpha_{9}$ \\
\hline $\begin{array}{c}\text { Determination } \\
\text { coefficient } R^{2}\end{array}$ & 0,1008 & & & & & \\
\hline $\bar{A}$ & & $-0,4152$ & $-0,0841$ & 0,0117 & $-0,0191$ & 0,0507 \\
\hline Standard errors & 0,2275 & 0,029 & 0,0082 & 0,0024 & 0,0017 & 0,0016 \\
\hline p-value & $\mathbf{0}$ & 0 & 0 & 0 & 0 & 0 \\
\hline $\begin{array}{c}\text { HAC standard } \\
\text { errors* }\end{array}$ & & 0,0355 & 0,0106 & 0,007 & 0,005 & 0,002 \\
\hline $\begin{array}{c}\text { HAC p-value } z- \\
\text { test } * * *\end{array}$ & & 0 & 0 & 0 & 0 & 0 \\
\hline $\begin{array}{c}\text { HAC p-value } t- \\
\text { test } t^{* * *}\end{array}$ & & 0 & 0 & 0,09 & 0 & 0 \\
\hline
\end{tabular}

$*, * *, * * *-$ to tackle errors serial correlation and heteroscedasticity HAC covariance matrix was estimated.

Source: own work.

DOI: $10.7862 /$ rz.2016.mmr.26 
Tekst złożono w redakcji: czerwiec 2016

Przyjęto do druku: wrzesień 2016 